Georgia State University

ScholarWorks @ Georgia State University

Computer Information Systems Faculty

Publications

Department of Computer Information Systems

$12-2015$

\title{
Fit and Misfit of Plural Sourcing Strategies and IT-Enabled Process Integration Capabilities: Consequences of Firm Performance in the U.S. Electric Utility Industry
}

\author{
Arun Rai \\ Georgia State University, arunrai@gsu.edu \\ Ilgaz Arikan \\ Kent State University, iarikan@kent.edu \\ Jessica Pye \\ Georgia State University, jessica.pye@eci.gsu.edu \\ Amrit Tiwana \\ Georgia State University, tiwana@uga.edu
}

Follow this and additional works at: https://scholarworks.gsu.edu/cis_facpub

Part of the Management Information Systems Commons

\section{Recommended Citation}

Rai, A., Arikan, I., Pye, J. and Tiwana, A., Fit and Misfit of Plural Sourcing Strategies and IT- Enabled Process Integration Capabilities: Consequences for Firm Performance in the U.S. Electric Utility Industry, MIS Quarterly, 39(4), 2015, 865-885. http://misq.org/fit-and-misfit-of-plural-sourcing-strategies-and-itenabled-process-integration-capabilities-consequences-of-firm-performance-in-the-u-s-electric-utilityindustry.html.

This Article is brought to you for free and open access by the Department of Computer Information Systems at ScholarWorks @ Georgia State University. It has been accepted for inclusion in Computer Information Systems Faculty Publications by an authorized administrator of ScholarWorks @ Georgia State University. For more information, please contact scholarworks@gsu.edu. 


\title{
FIT AND MISFIT OF PlURAL SOURCING STRATEgIES AND IT-ENABLED PROCESS INTEGRATION CAPABILITIES: CONSEQUENCES OF FIRM PERFORMANCE IN THE U.S. ELECTRIC UTILITY INDUSTRY ${ }^{1}$
}

\author{
Arun Rai \\ Center for Process Innovation and Department of Computer Information Systems, \\ Robinson College of Business, Georgia State University, \\ Atlanta, GA 30303 U.S.A. \{arunrai@gsu.edu\} \\ Ilgaz Arikan \\ College of Business Administration, Kent State University, \\ Kent, OH 44242 U.S.A. \{iarikan@kent.edu\} \\ Jessica Pye \\ Center for Process Innovation and Department of Computer Information Systems, \\ Robinson College of Business, Georgia State University, \\ Atlanta, GA 30303 U.S.A. \{jessica.pye@eci.gsu.edu\} \\ Amrit Tiwana \\ Terry College of Business, University of Georgia, \\ Athens, GA 30602 U.S.A. \{tiwana@uga.edu\}
}

Recent work has shown that a firm's plural sourcing strategy, which determines how much it chooses to make versus how much it chooses to buy, requires consideration of the complementarities and constraints that affect the differential advantages of making and buying. Elaborating on this perspective, we theorize how (mis)fit between a firm's plural sourcing strategy of simultaneously making and buying and its development of information technology (IT) enabled interfirm and intrafirm process integration capabilities influences firm performance in deregulated markets. We position our theory development and empirical tests in the context of the power-generation segment of the U.S. electric utility industry (EUI), an asset-intensive industry that has been deregulated to promote the separation of key value chain activities (i.e., generation, transmission, and distribution) and the development of wholesale energy markets. We draw on the transaction cost economics, coordination costs, and IT capabilities perspectives to theorize that a firm achieves fit (realizing performance benefits) by increasing market sourcing intensity (MSI)—or, how much it buys relative to how much it makesand developing IT-enabled interfirm process integration capability for external coordination with the market, or misfit (realizing performance penalties) by increasing MSI and developing IT-enabled intrafirm process integration capability for coordinating internal production. We collated data from archival sources for 342 utility firms in the power-generation segment to construct a panel dataset for the period 1994-2004 on

\footnotetext{
${ }^{1}$ Anandhi Bharadwaj was the accepting senior editor for this paper. Sunil Mithas served as the associate editor.

The appendices for this paper are located in the "Online Supplements" section of the MIS Quarterly's website (http://www.misq.org).
} 
(1) firms' MSI from wholesale electricity markets, (2) firms' IT investment decisions to develop interfirm and intrafirm process integration capabilities, (3) measures of firm performance, and (4) several control variables related to exogenous shocks (i.e., regulatory change, oil crisis), region of operation, and firm-level factors. Our results suggest that fit between MSI and the development of IT-enabled interfirm process integration capability improves firm profitability, assessed by return on assets, and misfit between MSI and the development of IT-enabled intrafirm process integration capability extracts penalties in firm profitability. We also find evidence that fit between MSI and the development of IT-enabled interfirm process integration capability improves market valuation, assessed by Tobin's $Q$, and asset turnover, assessed by operating revenue/total assets. We discuss the implications of our findings for the development of IT capabilities to accompany a firm's plural sourcing strategy and the literature on IT business value.

Keywords: Plural sourcing, market sourcing intensity, IT-enabled process integration, IT capabilities, firm performance, IT business value

\section{Introduction}

Plural sourcing, also referred to by some scholars as concurrent sourcing, involves a firm's simultaneous use of multiple modes of governance to source a good/service (Parmigiani 2007; Puranam et al. 2013). It involves a firm making and buying a good/service that entails splitting the total sourced volume between internal production (hierarchical governance) and markets (price governance). A firm's use of hybrid governance that combines the market and the firm to source the total volume of a good/service has developed as a broad phenomenon across product-market contexts. While most theories of the firm have viewed the sourcing decision of a good/service as a dichotomous make versus buy choice (Grant 1996; Williamson 1975), firms across diverse industries including automotive (Gulati et al. 2005), banking (Jacobides and Hitt 2005), machine tools (Parmigiani 2007), and fashion garments (Jacobides and Billinger 2006) simultaneously use external procurement and internal production to source the good/service (Parmigiani 2007).

Given the misfit of the plural sourcing phenomenon with the dominant theories of the firm that have concentrated on make versus buy decisions, recent work in strategic management has developed and tested explanations of a firm's motivations and benefits of making and buying, or plural sourcing, a good/service (Gulati et al. 2005; Parmigiani 2007) and has focused on understanding the complementarities and constraints that affect the effectiveness of plural sourcing strategies, or how much to make versus how much to buy (Puranam et al. 2013). This recent work shows that plural sourcing represents a way for a firm to simultaneously monitor suppliers, produce efficiently, and improve performance and that the effectiveness of plural sourcing strategies depends on capabilities and constraints that are heterogeneously distributed across firms and not only on exogenous transaction characteristics.
Although there is broad recognition that IT capabilities are heterogeneously distributed across firms and are sources of business value for firms (Aral and Weill 2007; Bharadwaj 2000; Bharadwaj et al. 1999; Melville et al. 2004; Soh et al. 2006), the role of IT capabilities in affecting business value given a firm's plural sourcing choices is unclear. Past work has shown that (1) interorganizational systems enable the integration of interfirm processes and the coordination of transactions in the market ${ }^{2}$ while intrafirm systems improve the coordination of work activities within the firm (Morris and Venkatesh 2010), (2) performance benefits of specific IT capabilities are amplified or attenuated based on their fit or misfit with governance choices (Mani et al. 2010), and (3) interfirm IT capabilities enhance value cocreated in interfirm relationships when accompanied by relational governance practices (Rai et al. 2012). However, the business value of developing interfirm and intrafirm IT capabilities has not been examined alongside a firm's use of plural sourcing to govern a transaction, leaving it unclear as to how a firm's use of plural sourcing can change the value of developing interfirm and intrafirm IT capabilities. We address this gap by focusing on the following research question: How does the (mis)fit between a firm's plural sourcing strategies and the development of IT-enabled interfirm and intrafirm process integration capabilities influence firm performance?

Our study is situated in the power-generation segment of the U.S. electric utility industry (EUI), a critical, deregulated, asset-intensive industry where aligning supply and demand of electricity is essential for firm performance. We introduce the concept of market sourcing intensity (MSI), defined as the

\footnotetext{
${ }^{2}$ For example, interorganizational systems can enable electronic markets (Choudhury et al. 1998), global service disaggregation (Mithas and Whitaker 2007), process integration in business process outsourcing (Mani et al. 2010, Mani et al. 2011), supply chain integration (Rai et al. 2006), and customer relationship management (Ray et al. 2005).
} 
extent to which a firm sources electricity through external procurement relative to internal production, to represent plural sourcing by a firm. We build on the transaction cost economics (TCE), coordination costs, and IT capabilities perspectives to theorize $f i t$, where a firm develops IT-enabled interfirm process integration capability as it increases market MSI, and misfit, where a firm develops IT-enabled intrafirm process integration capability as it increases MSI. We test these ideas by collating data from archival sources for 342 utility firms in the power-generation segment and constructing a panel dataset for the period 1994-2004 that included 6,685 IT investments decisions made by firms. We find that the proposed fit and misfit of IT-enabled process integration capabilities with MSI explain firm performance above and beyond either the IT capabilities or the TCE perspectives alone. By surfacing the interdependencies between plural sourcing strategies and the development of IT capabilities, our study contributes to our understanding about IT business value, IT capabilities, and plural governance choices.

\section{Investigative Context}

The EUI is among the largest sectors of the U.S. economy, with many sectors of the economy depending on it. Approximately 7 percent of the U.S. GDP, or about $\$ 1$ trillion, is spent on energy, with retail electricity accounting for $\$ 350$ billion of the energy market. ${ }^{3}$ The EUI's well-defined value chain activities (generation-transmission-distribution ${ }^{4}$ ) enable us to specify and precisely measure the plural sourcing transaction $^{5}$ (i.e., power generation). Moreover, the EUI was deregulated to introduce competition in the generation of electricity, to promote the unbundling of generation from transmission and distribution, and to develop wholesale markets by providing nondiscriminatory access to the transmission system and increasing transparency of the bulk transmission system. These fundamental changes triggered firms to reevaluate their single-source reliance policies and made plural sourcing a salient managerial choice.

\footnotetext{
${ }^{3}$ See CIA World Factbook (2011); Energy Information Administration Report (Repice et al. 2012).

${ }^{4}$ Generation is the production of electric energy from other energy sources, transmission is the delivery of electric energy over high-voltage lines from the power plants to the distribution areas, and distribution includes the local system of lower voltage lines, substations, and transformers that delivers electricity to end-consumers.

${ }^{5}$ Measured as the proportion of electricity sold that is purchased in the wholesale market vs. produced internally, consistent with Lieberman (1984) and Jacobides and Winter (2005).
}

Importantly, electricity is the perfect commodity, removing confounds of product characteristics, inventories, and logistics for purposes of our theory development and research design. Unlike physical commodities (e.g., chemicals) whose attributes vary in quality, grade, and logistics, electricity is standardized, differing only in location, period of delivery, and stability (Ku 2000). Furthermore, as electricity cannot be stored economically, its supply has to match demand at a precise point in time to avoid shortages (Polk 2001). Given these product-market characteristics, a firm's MSI (i.e., the use of wholesale markets relative to internal power generation) along with its abilities to produce electricity internally and to align demand with wholesale supply have been identified as factors that influence performance (Joskow 1989). As a result, the industry has witnessed rapid-fire IT innovations not only for prediction of demand and coordination and control of a firm's internal production but also for external coordination to dynamically align wholesale supply with customer demand. These innovations have triggered firms to invest in the development of interfirm and intrafirm process integration capabilities to coordinate external procurement and internal production, respectively.

In sum, the EUI provides an ideal context to conceptualize and measure a firm's plural sourcing choice (i.e., MSI), conceptualize and measure the development of two IT capabilities - for internal production (i.e., intrafirm process integration capability) and for aligning procurement from wholesale markets with customer demand (i.e., interfirm process integration capability) - and examine the consequences of (mis)fit of MSI with the development of these two IT capabilities.

\section{Theoretical Development}

Our research model and hypotheses are shown in Figure 1. The core idea underlying the model is that of discriminating alignment between the development of IT capabilities and changes in plural governance of a sourcing transaction: fit (misfit) of the development of IT-enabled process integration capabilities with increases in MSI exacts performance benefits (penalties). This idea informs the two hypotheses, the first representing fit between the development of IT-enabled interfirm process integration capability and increases in MSI that enhances firm performance and the second representing misfit between the development of IT-enabled intrafirm process integration capability and increases in MSI that decreases firm performance. The model recognizes that both costs to transact in the market and costs to internally organize production influence a firm's sourcing choices (Masten et al. 1991), 


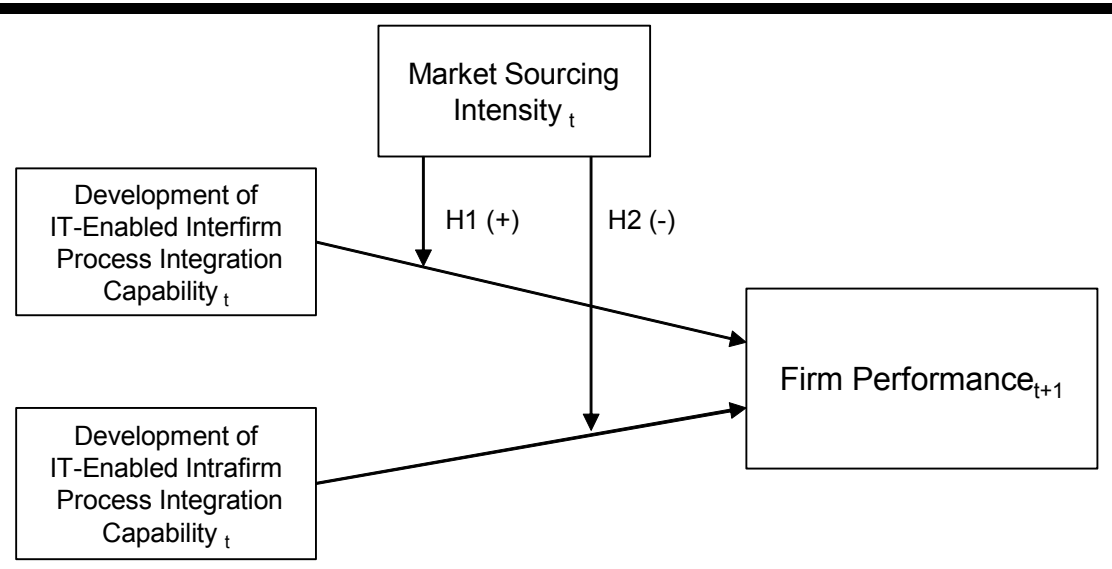

Note: Control variables not shown for clarity.

Figure 1. Research Model

specifically make-and-buy decisions or reliance on the market versus internal production (Puranam et al. 2013), and the firm can alter costs to transact in the market and costs to internally organize production by developing capabilities (Puranam et al. 2013), specifically IT-enabled interfirm process integration capabilities to reduce costs to transact in the market and ITenabled intrafirm process integration capabilities to reduce costs to internally organize production.

\section{Market Sourcing Intensity}

As Parmigiani (2007, p. 287) notes, "transaction cost economics has been intriguingly silent on the question of concurrent sourcing." She observes that numerous empirical studies grounded in TCE have collapsed plural sourcing choices to a dichotomous make-or-buy decision by forcing the issue. For example, Monteverde and Teece (1982) define a firm's sourcing choice to be "make" when it produces at least 80 percent of its requirements and "buy" when it produces less than 80 percent of its requirements. Studies that have integrated TCE and capabilities perspectives have also framed a firm's boundary choice of a transaction as a dichotomous make-and-buy decision (e.g., Leiblein and Miller 2003; Steensma and Corley 2001), thereby not considering the possibility that the firm can simultaneously rely on both the market and internal production to govern the same transaction.

We focus on understanding how firm performance is impacted by the interactions of plural sourcing strategiesdefined as how much a firm chooses to simultaneously source from the market and internal production (Puranam et al. 2013) - and the development of IT capabilities for interfirm and intrafirm process integration. We advance the logic that a firm's marginal returns from IT-enabled interfirm and intrafirm process integration capabilities change with the extent of reliance on the market relative to internal production to govern a sourcing transaction.

As the conceptualization and measurement of governance choices of a transaction requires defining the focal transaction and the transaction's scope in the value chain (Williamson 1985), we specify power generation as the focal transaction and the transaction's scope as spanning the generation and transmission stages in the electricity value chain. We measure MSI as follows based on the megawatt-hours (MWh) purchased versus internally generated by a firm:

$$
\text { MSI }_{i t}=\frac{\text { MWhPurchased }_{i t}}{\text { MWhInternally_Eenerated }_{i t}+\text { MWhPurchased }_{i t}}
$$

where MWhInternallyGenerated ${ }_{i t}=M W h$ generated internally by Utility $i$ in Year $t$

MWhPurchased $_{i t}=$ Electricity in total MWh purchased by Utility $i$ in Year $t$

As electricity cannot be stored efficiently and supply shortages can be compensated by wholesale purchases, the makebuy ratio in net generation (proportion of the total output sold by a firm that is bought on the market as opposed to internally produced) is a good proxy for the extent of a firm's plural sourcing of electricity. It corresponds to Parmigiani's assessment of plural sourcing of goods in the metal stamping and power metal firms for producing tooling and services, where she captured whether the firm was making, buying, or making-and-buying and also the extent to which the firm was producing the good internally if it was making-and-buying. It is also similar to Jacobides and Hitt's (2005) measure in the 


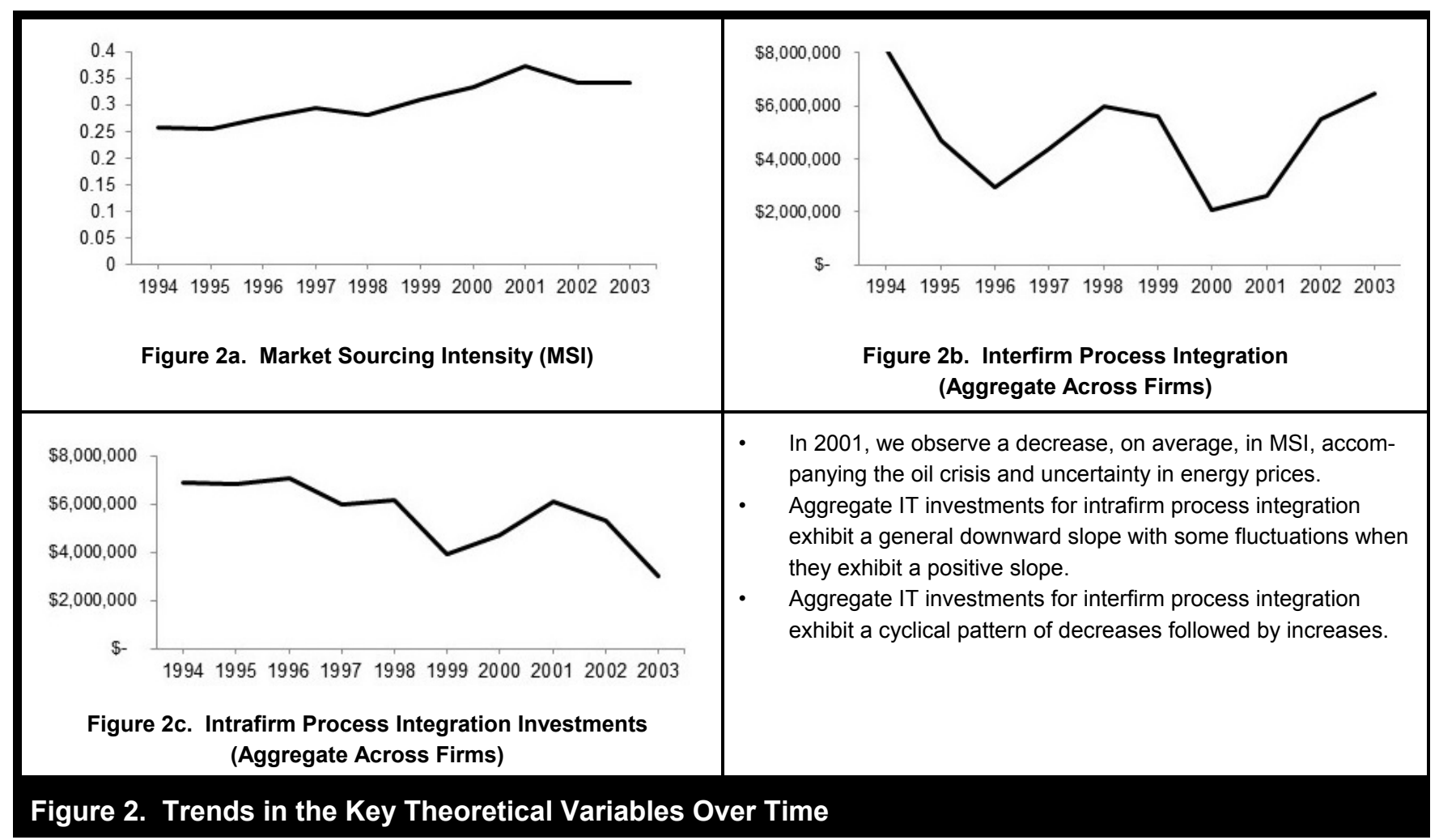

banking industry of a bank's reliance on internal capacity versus external sourcing of loan production (dollar value ratio of loans produced by a bank through its internal branches to the total dollar value of loans produced in a given year including external brokers and other agents).

Figure 2a shows the trend over time in MSI in the powergeneration segment of the EUI. While firms, on average, increased MSI in the duration of our study period, they decreased MSI in 2001 in response to the oil crisis (Figure 2a), consistent with the expectation that firms increase internalization of transactions and reduce reliance on markets when there is an increase in supply uncertainty (Sutcliffe and Zaheer 1998). Furthermore, significant industry deregulation by the Federal Energy Regulatory Commission (FERC) encouraged the emergence of electricity wholesale markets, which motivated firms to reevaluate how much power to source in the wholesale market versus produce internally. ${ }^{6}$

${ }^{6}$ FERC Orders 888 and 889 implemented in 1996 required utilities that owned transmission facilities to file open access transmission tariffs that defined the terms and conditions of available transmission services available to wholesale generators and to make this information available in real-time through electronic means by way of an Open Access Same-Time Information System (OASIS). Order 888 also provided for the recovery of stranded costs by public utilities, which arose as a result of deregulation. This was to be
We next develop our logic for (mis)fit between the development of IT-enabled process integration capabilities and MSI and the implications for firm performance.

\section{Interdependencies Between IT-Enabled Process Integration Capabilities and MSI}

In contrast to hybrid modes of governance where the total volume of a good/service is procured from a single source by combining characteristics of firms and markets (Gulati et al. 2005; Williamson 1991), plural sourcing allocates the total sourced volume across the market and internal production (Puranam et al. 2013). By pursuing plural sourcing, a firm incurs costs for internal production (e.g., capital, plant and equipment capacity, staffing, and coordination) and external procurement (e.g., searching, selecting, negotiating, contracting, and monitoring suppliers) (Parmigiani 2007). However, the suggested benefits of plural sourcing include compensating for the limitations of internal production by capitalizing on cost advantages, reduced bureaucratic obstacles, and flexibility of market sourcing (Parmigiani

FERC's first broad-sweeping effort to eliminate discriminatory and unfair practices in the transmission system (Liggett et al. 2000). 
2007; Williamson 1975), and motivating and learning about improvements in internal production by simultaneously monitoring suppliers and internal production (Puranam et al. 2013).

Traditional explanations of a firm's transaction boundaries, particularly those explanations that rely only on transaction costs analysis, provide a partial explanation of how a firm sources a good and formulates make versus buy decisions. As per TCE, a firm's governance choice is influenced by transaction costs - or the costs to coordinate and integrate activities in the market. Although TCE considers the costs of transacting in the market, it did not initially consider the costs of organizing a transaction within a firm, or what Masten et al. (1991) refer to as the costs of internal organization. Remedying this omission, the subsequent TCE literature emphasized that a firm's governance choice is intended to economize on costs of a transaction (Williamson 1999), and the relative costs of coordinating the transaction internally and in the market should influence governance choice. The TCE literature also suggests that the relative costs of coordinating transactions internally or externally are influenced not only by exogenous factors (e.g., regulatory shocks and supply crises) but also by firm capabilities (Argyres 1999; Jacobides and Winter 2005; Williamson 1999). Moreover, the factors that motivate a firm away from buying may not be the same as the ones that motivate it toward making (Parmigiani 2007). Consequently, a firm's capabilities to coordinate a transaction in the market and to organize it internally are distinct and should influence MSI. By extension, MSI should motivate a firm to invest in developing capabilities to either coordinate a transaction in the market or organize it internally. This leads to a reciprocal relationship between MSI and capabilities to coordinate a transaction in the market and organize it internally. ${ }^{7}$ From an IT business value perspective, this reciprocal relationship motivates an assessment of how changes in MSI affect the business value of IT-enabled process integration capabilities related to sourcing a good/service in the market and internally organizing production of the good/service.

IT-enabled process integration capabilities have been examined in various contexts, for example, manufacturing,

\footnotetext{
${ }^{7}$ Our conceptualization of reciprocal influence of MSI and development of IT-enabled process integration capabilities is consistent with Markus and Robey's (1988) emergent perspective, where a dominant causal agency is not ascribed to either the IT variables or the organization variables. The emergent perspective is in contrast to the technological imperative, where the decision to develop IT capability (interfirm or intrafirm process integration) precedes decisions to change the extent of plural sourcing (IT is superordinate) or the organizational imperative, where the decision to change plural sourcing precedes the development of IT capabilities (IT is subordinate).
}

procurement, production, marketing, business process outsourcing, supply chain management, and customer relationship management (Bharadwaj et al. 2007; Gattiker and Goodhue 2005; Mishra et al. 2013; Rai et al. 2006; Rai and Tang 2010; Ranganathan and Brown 2006; Ray et al. 2005). A key conclusion from this past work is that interfirm process integration capabilities reduce transaction costs in markets while intrafirm process integration capabilities reduce organization costs of internal production. Differentiating between interfirm and intrafirm process integration capabilities, we define interfirm process integration as the degree to which a firm establishes digital connections with entities outside the firm's boundaries to coordinate transaction interdependencies with them, and intrafirm process integration as the degree to which a firm establishes digital connections among the resources and activities in internal subunits and functions to coordinate production interdependencies. IT investments in supplierand customer-facing systems that enable a firm to align supply with real-time demand can be used to develop the interfirm process integration capability, and internal systems to coordinate internally distributed production resources and activities can be used to develop the intrafirm process integration capability. In the EUI's power-generation segment, firms can invest in systems and technologies such as electronic data interchange and supply chain management systems to coordinate activities with wholesale suppliers and in systems and technologies such as automated meter reading systems and customer relationship management systems to coordinate activities with customers. Firms can also invest in systems and technologies such as supervisory data control and acquisition (SCADA) to coordinate their internally distributed production activities and resources for increased reliability and efficiency in power generation. Figures $2 b$ and $2 c$ show the trends in interfirm/intrafirm process integration investments over time in the power-generation segment of the EUI. We now examine the (mis)fit between developing interfirm/ intrafirm process integration capabilities and MSI, and the consequences for firm performance.

\section{Conceptualizing Fit and Misfit of IT-Enabled Process Integration Capabilities and MSI}

Our conceptualization of fit is grounded in Williamson's (1999) view of discriminating alignment and is operationalized using Venkatraman's (1989) typology of fit. Williamson (1999, p. 1090) emphasized the need for theorizing how a firm's governance choices occur in the context of what he describes as its "distinctive strengths and disabilities," or firm-specific capabilities. He emphasizes the need for matching a firm's governance choices with its capabilities to generate superior firm performance. We build on Williamson's (1999) notion of discriminating alignment and related 
work (e.g., Nickerson and Zenger 2002) to understand the (mis)alignment between a firm's development of IT-enabled process integration capabilities and its decision to increase/ decrease MSI. Extending Williamson's (1999) idea that a firm's capabilities influence its costs of transacting in the market and internally organizing the transaction, we suggest that a firm achieves fit when an increase in MSI is accompanied by the development of IT-enabled interfirm process integration capability and devolves into misfit when an increase in MSI is accompanied by the development of ITenabled intrafirm process integration capability. This conceptualization of (mis)fit is guided by Venkatraman's notion of fit as moderation that is appropriate when the variables involved in the fit relationship have high specificity and the interaction of the variables is posited as the primary determinant of the variance in a criterion variable. These conditions match the specificity of our predictors and criterion variables (i.e., MSI, the development of IT-enabled process integration capabilities, and firm performance) and our theorizing interactions among the predictors to explain variance in firm performance.

\section{Fit Between IT-Enabled Interfirm Process Integration Capability and MSI}

A firm's interfirm process integration capability provides the firm with the ability to monitor partners' actions, coordinate resource flows and activities with partners, and reduce transaction costs (Bharadwaj et al. 2007; Rai et al. 2006; Rai and Tang 2010; Robey et al. 2008; Subramani and Venkatraman 2003). For example, the development of the B-2 "Stealth" Bomber involved several hundred contractors who successfully used a centralized interfirm system to manage interdependencies among the work activities of various contractors (Argyres 1999). This system provided the focal firm with a mechanism to electronically observe the work of individual contractors and to orchestrate the execution of distributed activities. Interfirm process integration capability can also enable a firm to effectively synchronize supply with demand and to offer customers novel services based on monitoring of their real-time consumption, For example, CenterPoint Energy, a Houston-based utility firm, decided to invest $\$ 640$ million over a five-year period in automated metering systems (AMS) to cover more than 2-million electric meters across its 5000-square mile electric service territory (Boone and Hackeny 2009). This system provides CenterPoint Energy's customers with granular consumption information that they can track over the web. Access to this information enables customers to make informed consumption and energy conservation choices and to act on these choices by remotely operating thermostats and appliances. It also provides CenterPoint Energy with real-time consumption information, enabling it to more effectively load utility assets, source in wholesale markets, and serve customers (e.g., remotely connecting and disconnecting services, monitoring outages and responsively acting on them).

Moreover, interfirm process integration capability can ensure standards compliance in the absence of direct authority and ownership to govern a transaction by automating the enforcement of activity and output standards. As a firm organizes a greater proportion of a transaction in the market, it loses direct authority, formal channels for information flows, and bureaucracy that can be applied to govern the transaction within the firm, thereby increasing external coordination costs (Langlois 1992). Developing interfirm process integration capability can compensate for these increases in external coordination costs and the lack of observability of work done outside the firm's boundaries that accompanies increased MSI. We therefore hypothesize complementarity between MSI and the development of interfirm process integration capability in enhancing firm performance.

\begin{abstract}
Hypothesis 1: The marginal returns to firm performance from developing IT-enabled interfirm process integration capability increase with an increase in market sourcing intensity.
\end{abstract}

\section{Misfit Between IT-Enabled Intrafirm Process Integration Capability and MSI}

A firm's intrafirm process integration capability provides the firm with the ability to control and coordinate interdependent tasks and activities across its internal subunits and functions (Bardhan et al. 2006; Gattiker and Goodhue 2005). For example, Vineland Municipal Electric Utility, a New Jersey based utility, is implementing a state-of-the-art SCADA system (SourceOne 2014). This system will establish a central location to efficiently monitor the power generation infrastructure and unexpected fluctuation in power generation activities such as generation of energy from renewable sources, emergency situations, equipment failure, and error resolution. The system is expected to improve operating reliability as well as better manage distributed power generation. Increases in MSI shift the onus to coordinating activities across a firm's boundary in contrast to decreases in MSI where the firm faces a greater need to coordinate activities within the firm (Masten et al. 1991). As a result, with increases in MSI, the costs of internally organizing a transaction become less important vis-à-vis the costs of coordinating it in the market. Therefore, a firm is less likely to realize performance gains from developing intrafirm process integration capability when it increases MSI. When a firm invests in developing intrafirm process integration capability 
while increasing MSI, it misaligns the capability being developed with the increasing reliance being placed on the market for sourcing a good/service. As misalignment between a firm's capabilities and governance choice should exact performance penalties (Williamson 1999), we expect increases in MSI to diminish the performance gains from developing intrafirm process integration capability.

Hypothesis 2: The marginal returns to firm performance from developing IT-enabled intrafirm process integration capability decrease with an increase in market sourcing intensity.

\section{The Empirical Study}

\section{Panel Dataset Construction}

Our unit of analysis is the firm. We constructed a panel dataset using multiple archival sources of firm-year observations for 342 major power-generation utility firms in the United States. These firms collectively produce about 80 percent of the electricity in the United States. The Department of Energy (DOE), which oversees the Energy Information Administration (EIA) and the FERC, mandates utility firms to file various financial and operating reports with the EIA and the FERC. As part of the reporting mandates, firms are required to report all significant IT and non-IT investments undertaken as construction-work-in-process (CWIP), ${ }^{8}$ or fair market value of assets developed, that year. ${ }^{9}$ Thus, CWIP in the EUI represents the fair market value of investments by a firm to develop its capabilities, and IT investments comprising CWIP is a good proxy of the firm's enacted decisions to develop IT capabilities.

We extracted each firm's financial and operational reports filed with the EIA and the FERC between 1994 and 2004. Although firms are required to follow a uniform system of accounts in filing reports, we detected a few inconsistent descriptions in the reports filed by some firms. We clarified each inconsistency using phone interviews with the conformity officers at these firms. We obtained missing financial and accounting information from Wharton Research Data

\footnotetext{
${ }^{8}$ The FERC's reporting guidelines define a significant investment to be at least $5 \%$ of overall CWIP or exceeding $\$ 100,000$, whichever is less, and require investments less than $\$ 100,000$ to be grouped together as a single entry.

${ }^{9}$ If an investment spans years (such as implementation of a SCADA system), firms are required to use FERC Form 730 to provide granular investment activity reports that break down fair market values across years.
}

Service (WRDS). Through our collation of data from the various sources, we developed a rich dataset comprising 6,685 significant IT investments made across firms in the 19942003 period, internal generation and market sourcing of electricity, and a range of control variables in the 1994-2003 period, and various performance measures in the 1994-2004 period.

\section{Coding Scheme for IT Investment Decisions}

We use a firm's IT investments as a proxy for its development of IT-enabled process integration capabilities based on the logic that investment size represents the emphasis by a firm on developing a capability (Argyres 2011). We developed coding criteria to determine if an IT investment was directed at (1) interfirm process integration, (2) intrafirm process integration, (3) standalone (or modular) intrafirm systems, (4) standalone (or modular) interfirm systems, or (5) generalpurpose IT infrastructure. Collectively, these types of IT investments are mutually exclusive and collectively exhaustive. We also coded whether the IT investment was directed at customizing IT. Investments in standalone (modular) systems, IT infrastructure, and IT customization are used as controls. The coding scheme is summarized in Table 1. We now elaborate on our three-phase process to code the IT investments and validate the coding.

\section{Phase 1: Initial Classification}

We first evaluated whether each IT investment was directed at business processes or IT infrastructure (INFRA). Subsequently, for investments in business processes, we determined if the investments were in systems that integrate activities and resources or in standalone systems. We also classified the investments that were directed at customizing IT resources. We then iteratively refined the coding scheme through telephone interviews with IT industry experts, academic experts, utility industry professionals, conformity officers at the utility firms responsible for filing FERC reports, FERC officers responsible for maintaining the FERC datasets, and reports from IT vendors that provided the products and services to the firms. Next, two coders, one with a master's degree in business administration and information systems and the other with a master's degree in economics and international business, were trained on the classification rules and coded the IT investment descriptions for 1994-1995. Their initial interrater reliability for the coded 1994-1995 IT investments was at an acceptable level of 94.5 percent (Neuendorf 2002). The differences in the coding results were discussed with conformity officers and plant engineers at a large Southeastern 
Table 1. Coding Scheme for IT Investment Decisions by a Firm

\begin{tabular}{|c|c|c|}
\hline $\begin{array}{l}\text { Type of IT investment } \\
\text { (Informing Sources) }\end{array}$ & $\begin{array}{l}\text { Decision Rule Applied to IT Investment } \\
\text { Description Provided in Filed Reports }\end{array}$ & Illustrative IT Investments \\
\hline $\begin{array}{l}\text { Development of Intrafirm } \\
\text { Process Integration Capability } \\
\text { (Barki and Pinsonneault 2005; } \\
\text { Bharadwaj et al. 2007; Rai et al. } \\
\text { 2006; Saraf et al. 2007) }\end{array}$ & $\begin{array}{l}\text { Is the investment in an integrated system } \\
\text { that coordinates internal production } \\
\text { activities (e.g., planning, monitoring, } \\
\text { and/or controlling)? If yes, the firm made } \\
\text { a decision to invest in developing its } \\
\text { intrafirm process integration capability to } \\
\text { coordinate internal production. }\end{array}$ & $\begin{array}{l}\text { - Supervisory control and data acquisition } \\
\text { (SCADA) system } \\
\text { - Integrated automated mapping and } \\
\text { facilities management (AM/FM) system } \\
\text { - Energy generation control system }\end{array}$ \\
\hline \multirow[t]{4}{*}{$\begin{array}{l}\text { Development of Interfirm } \\
\text { Process Integration Capability } \\
\text { (Rai et al. 2006; Rai and Tang } \\
\text { 2010; Ross et al. 2006; Saraf et } \\
\text { al. 2007) }\end{array}$} & $\begin{array}{l}\text { Is the investment in an integrated system } \\
\text { that coordinates activities with suppliers or } \\
\text { customers? If yes, the firm made a } \\
\text { decision to invest in developing its } \\
\text { interfirm process integration capability to } \\
\text { coordinate supply with demand. }\end{array}$ & \\
\hline & $\begin{array}{l}\text { a Is the investment in a system that } \\
\text { coordinates activities with suppliers? }\end{array}$ & $\begin{array}{l}\text { - Integrated supply chain planning } \\
\text { - E-Procurement } \\
\text { - Supply chain materials management } \\
\text { - Supplier contract management } \\
\text { - Multi-vendor electronic data interchange } \\
\text { system }\end{array}$ \\
\hline & $\begin{array}{l}\text { b. Is the investment in a system that } \\
\text { coordinates activities with customers? }\end{array}$ & $\begin{array}{l}\text { - Automated meter reading system } \\
\text { - Meter rerouting system } \\
\text { - Energy delivery mobile system } \\
\text { - Customer order fulfillment system } \\
\text { - Customer service systems } \\
\text { - Client development system }\end{array}$ \\
\hline & $\begin{array}{l}\text { c. Is the investment in a system that } \\
\text { coordinates activities with customers } \\
\text { or suppliers? }\end{array}$ & - Electronic data interchange system \\
\hline $\begin{array}{l}\text { Intrafirm IT Modularization* } \\
\text { (Baldwin 2008; Khanna et al. } \\
\text { 1998; Rai and Tang 2010; Ross } \\
\text { 2003; Saraf et al. 2007; Tiwana } \\
\text { 2008) }\end{array}$ & $\begin{array}{l}\text { Is the investment in an autonomous, } \\
\text { function-specific IT system for an intrafirm } \\
\text { activity? If yes, the firm made a decision } \\
\text { to invest in modularizing its intrafirm IT } \\
\text { systems. }\end{array}$ & $\begin{array}{l}\text { - Plant performance analysis } \\
\text { - Burner management module } \\
\text { - Fuel management module } \\
\text { - Turbine control system } \\
\text { - Environmental data acquisition (with } \\
\text { Graphical/Visual Processing Unit) } \\
\text { - Transformer outage information system }\end{array}$ \\
\hline $\begin{array}{l}\text { Interfirm IT Modularization* } \\
\text { (Bala and Venkatesh 2007; } \\
\text { Malhotra et al. 2005; Rai and } \\
\text { Tang 2010) }\end{array}$ & $\begin{array}{l}\text { Is the investment in an autonomous, } \\
\text { function-specific IT system for an interfirm } \\
\text { activity? If yes, the firm made a decision } \\
\text { to invest in modularizing its interfirm IT } \\
\text { systems. }\end{array}$ & $\begin{array}{l}\text { - Customer billing module } \\
\text { - Supplier performance analysis } \\
\text { - Backup meter interrogation software } \\
\text { - Reregulation requirements module } \\
\text { (added to customer information system) }\end{array}$ \\
\hline $\begin{array}{l}\text { IT Infrastructure* } \\
\text { (Aral and Weill 2007) }\end{array}$ & $\begin{array}{l}\text { Is the investment in hardware, databases, } \\
\text { and networks, and their interoperability? } \\
\text { If yes, the firm made a decision to invest } \\
\text { in its IT infrastructure. }\end{array}$ & $\begin{array}{l}\text { - Data integration/warehousing } \\
\text { - Integrated networking system } \\
\text { - Various operating systems } \\
\text { - Radio communication systems }\end{array}$ \\
\hline $\begin{array}{l}\text { IT Customization* } \\
\text { (Bharadwaj 2000; Klein and Rai } \\
\text { 2009; Williamson 1991) }\end{array}$ & $\begin{array}{l}\text { Is the investment in customizing } \\
\text { (including developing, enhancing or } \\
\text { modifying) the system to the unique } \\
\text { requirements of the firm? If yes, the firm } \\
\text { made a decision to invest in customizing } \\
\text { its IT resources. }\end{array}$ & $\begin{array}{l}\text { - Custom development of a communication } \\
\text { system } \\
\text { - Development of fuel management system } \\
\text { - Custom integration of computer systems }\end{array}$ \\
\hline
\end{tabular}

*Specified as control variables in the models 
Systems). After these clarifications, the coders recoded all of the IT investment descriptions for 1994-1995 and achieved a 96.7 percent inter-rater reliability. The coding of the IT investment descriptions for the remaining years was allocated evenly to the two coders.

\section{Phase 2: Interfirm Versus Intrafirm Process Integration Capabilities}

For investments in developing IT-enabled process integration capabilities, we further classified IT investments as directed at integrating intrafirm (INTRA) or interfirm (INTER) processes. We devised a coding scheme for this classification, applied it to a sample of about 10 percent of the IT investments (700 investments), and refined the coding scheme. We then trained one of the coders to apply the coding scheme. To ensure the validity of the coding, we inspected all the coding done by the coder for the first two years of IT investments (1,400 investments) and detected only a few (20) minor discrepancies; independently coded a random sample of about 20 percent of the IT investments in the remaining years and found the coding done by the coder to be very accurate (12 discrepancies); and randomly inspected 20 percent of the coded data once the coding was completed and detected only a couple of discrepancies which were resolved through discussion.

\section{Phase 3: Post-Coding Validation}

We used three steps to evaluate the external validity of the coding.

1. We conducted an in-person review with a senior IT executive of a EUI firm of our coding decisions for 25 IT investments at their firm. These IT investments included INTER, INTRA, INFRA and Customized/Generic investments. The executive agreed with all our 25 coding decisions.

2. We convened an in-person three-member IT executive panel, representing three EUI companies. We requested the panelists to individually code 40 IT investments (including INTER, INTRA, INFRA, and Customized/ Generic) into the types of IT investments that we had defined and to discuss discrepancies in their coding decisions with ours. There was complete agreement among the panelists with our coding decisions for 37 of the 40 IT investments including all our coding decisions for INTER, INTRA and INFRA. There was partial disagree- ment among the panelists on two coding decisions related to IT customization, with one disagreeing panelist observing that IT customization can accompany generic IT investment but the customization of generic IT resources may not be documented in a firm's FERC filings.

3. We requested two IT executives at two EUI firms to code the same set of 200 IT investments into the types of IT investments that we had defined. There was very high agreement between the IT executives' and our coding (97.5 percent and 98.5 percent, respectively, with each of the executives). There was only one case where both executives disagreed with our coding in that they coded one IT investment as customized while we coded it as generic. Discussions revealed that a similar generic IT system had been extended/customized at the executives' organization but the FERC description that we coded did not include this information. In all cases where there was disagreement between the executives' and our coding, discussions revealed that our coding was acceptable given the level of description provided in the FERC filings.

After the coding was completed, a firm's investments in each type of IT investment were aggregated to determine the relevant firm-year IT investments for 1994-2003.

\section{Construct Operationalization}

Table 2 summarizes the measures for the theoretical constructs as well as the instrumental and control variables. We elaborate on these measures below.

Firm Performance: We selected return on assets (ROA) as our measure for firm performance. As a measure of profits to total assets, it reveals how effectively firms have used their assets to grow profit levels (Tallon and Pinsonneault 2011). This is an especially appropriate measure of firm performance for our study given the asset-intensive nature of the EUI and our objective to understand how the extent of reliance on the wholesale market relative to internal production for the sourcing of electricity affects the value derived from IT investments. Furthermore, ROA is a broad measure of profitability, correlates with other measures of profitability, and has been widely employed in the IT business value literature (e.g., Aral and Weill 2007; Bharadwaj 2000; Rai et al. 1997).

MSI: We measured a firm's MSI in year $t$ as the ratio of total wholesale megawatt-hours purchased (the buy portion) to the sum of net megawatt-hours generated (the make portion) and purchased wholesale in that year (see Equation 1). 


\begin{tabular}{|c|c|c|}
\hline \multicolumn{2}{|l|}{ Variable } & \multirow[b]{2}{*}{ Operational Measure } \\
\hline Name & Type & \\
\hline Return on Assets (ROA) & Criterion & Net income divided by average total assets of a firm in a given year. \\
\hline Market Sourcing Intensity (MSI) & Predictor & $\begin{array}{l}\text { Ratio of total wholesale electricity purchased by a firm in a given } \\
\text { year to the sum of net megawatt-hours generated internally and } \\
\text { purchased wholesale by the firm in a given year. }\end{array}$ \\
\hline $\begin{array}{l}\text { Development of Interfirm Process } \\
\text { Integration Capability (INTER) }\end{array}$ & Predictor & $\begin{array}{l}\text { Total dollar amount spent by a firm in a given year on systems that } \\
\text { encompass multiple activities across the firm's boundary with } \\
\text { customers and suppliers. }\end{array}$ \\
\hline $\begin{array}{l}\text { Development of Intrafirm Process } \\
\text { Integration Capability (INTRA) }\end{array}$ & Predictor & $\begin{array}{l}\text { Total dollar amount spent by a firm in a given year on systems that } \\
\text { encompass multiple activities within the firm's boundary. }\end{array}$ \\
\hline $\begin{array}{l}\text { Interfirm IT Modularization } \\
\text { (INTER_MOD) }\end{array}$ & Control & $\begin{array}{l}\text { Total dollar amount spent by a firm in a given year on self- } \\
\text { contained, relatively autonomous systems that encompass activities } \\
\text { across the firm's boundary with suppliers and customers. }\end{array}$ \\
\hline $\begin{array}{l}\text { Intrafirm IT Modularization } \\
\text { (INTRA_MOD) }\end{array}$ & Control & $\begin{array}{l}\text { Total dollar amount spent by a firm in a given year on self- } \\
\text { contained, relatively autonomous systems that encompass activities } \\
\text { within the firm's boundary. }\end{array}$ \\
\hline IT Customization & Control & $\begin{array}{l}\text { Total dollar amount spent by a firm in a given year on customizing } \\
\text { systems to its unique requirements. }\end{array}$ \\
\hline IT Infrastructure & Control & $\begin{array}{l}\text { Total dollar amount spent by a firm in a given year on its IT } \\
\text { infrastructure. }\end{array}$ \\
\hline Supplier Concentration & Control & Herfindahl Index of supplier concentration for a firm in a given year. \\
\hline Oil Crisis Shock & Control & Time elapsed in years since the oil crisis in $2001 ; 0$ for $t<2001$. \\
\hline Depreciation Expense & Control & Depreciation expense incurred by a firm in a given year. \\
\hline Firm Age & Control & Number of years since a firm's incorporation. \\
\hline Production Capacity & Control & Total production capacity in MWh of a firm in a given year. \\
\hline $\begin{array}{l}\text { Non-IT Construction Work-In-Process } \\
\text { (CWIP_Other) }\end{array}$ & Control & $\begin{array}{l}\text { Total dollar amount spent by a firm in a given year on non-IT capital } \\
\text { work-in-process. }\end{array}$ \\
\hline Deregulation Shock & Control & $\begin{array}{l}\text { Time elapsed in years since the deregulation shock by FERC Order } \\
888 / 889 \text { implemented in } 1996 ; 0 \text { for } t<1996 \text {. }\end{array}$ \\
\hline Firm Location & Control & $\begin{array}{l}\text { Dummy variable for the principal NERC region of the state in which } \\
\text { the firm conducts business (firm location for states with more than } \\
\text { one NERC region coded separately). }\end{array}$ \\
\hline
\end{tabular}

Note: All financial performance and investment numbers in 2003 dollars

Development of IT-Enabled Process Integration Capabilities: We aggregated a firm's IT investments in year $t$ (i.e., CWIP, or fair market value of the development projects completed that year) to determine its development of intrafirm process integration and interfirm process integration capabilities in that year.

Measures for Control Variables: We specified several variables pertaining to other IT investments, firm characteristics, and industry events as controls, and measured them as we now describe.
Other IT Investments: We measured a firm's investments in IT infrastructure, standalone (modular) interfirm and intrafirm IT resources, and IT customization in year $t$ as these variables can influence interfirm governance (Klein and Rai 2009; Tiwana 2008) and firm performance (Aral and Weill 2007; Bharadwaj 2000; Rai et al. 1997).

Firm Characteristics: We measured firm age as the number of years since a firm's incorporation (Taylor and Fuller 1986); production capacity as total megawatt-hours of electricity generation capacity of a firm in year $t$ (Taylor and Fuller 1986); 


\begin{tabular}{|c|c|c|c|c|c|c|}
\hline Variable & Units & $\begin{array}{c}\text { Firm-Year } \\
\text { Observations }\end{array}$ & Mean & Std. Dev. & Min & Max \\
\hline $\mathrm{ROA}_{\mathrm{t}+1}$ & Ratio & 1164 & 0.05 & 0.06 & -1.55 & 0.46 \\
\hline $\mathrm{MSI}$ & Ratio & 1544 & 0.32 & 0.31 & 0.00 & 1.00 \\
\hline INTER* $^{*}$ & 2003 dollars & 1621 & 139.34 & 1920.97 & 0.00 & 45000.00 \\
\hline INTRA* & 2003 dollars & 1621 & 618.26 & 5055.25 & 0.00 & 108000.00 \\
\hline INTER_MOD* & 2003 dollars & 1621 & 629.37 & 3626.18 & 0.00 & 51400.00 \\
\hline INTRA_MOD* & 2003 dollars & 1621 & 1878.07 & 6406.73 & 0.00 & 99400.00 \\
\hline IT Customization* & 2003 dollars & 1621 & 1096.39 & 6819.98 & 0.00 & 136000.00 \\
\hline IT Infrastructure* & 2003 dollars & 1621 & 1681.75 & 6090.53 & 0.00 & 86700.00 \\
\hline Supplier Concentration & Ratio & 1201 & 0.42 & 0.33 & 0.02 & 1.00 \\
\hline Oil Crisis Shock & Years since 2001 & 2408 & 0.53 & 0.98 & 0.00 & 3.00 \\
\hline Depreciation Expenses* & 2003 dollars & 2139 & 90100.00 & 184000.00 & -3386.72 & 3140000.00 \\
\hline Firm Age & Years & 2150 & 63.71 & 34.85 & 0 & 191.00 \\
\hline Production Capacity & $\mathrm{MWh}$ & 1526 & 4215.71 & 14206.92 & 1.2 & 415001.70 \\
\hline CWIP_Other ${ }^{*}$ & 2003 dollars & 1542 & 94200.00 & 156000.00 & 0.00 & 1170000.00 \\
\hline Deregulation Shock & Years since 1996 & 2408 & 3.16 & 2.83 & 0.00 & 8.00 \\
\hline
\end{tabular}

Notes: *Indicates that the numbers are in thousands.

\section{Table 4. Correlation Matrix}

\begin{tabular}{|c|c|c|c|c|c|c|c|c|c|c|c|c|c|c|c|c|}
\hline & Variables & 1 & 2 & 3 & 4 & 5 & 6 & 7 & 8 & 9 & 10 & 11 & 12 & 13 & 14 & 15 \\
\hline 1 & $\mathrm{ROA}_{\mathrm{t}+1}$ & 1.000 & & & & & & & & & & & & & & \\
\hline 2 & $\mathrm{MSI}^{\mathrm{a}}$ & $0.072^{*}$ & 1.000 & & & & & & & & & & & & & \\
\hline 3 & INTER $^{b}$ & $0.082^{*}$ & -0.023 & 1.000 & & & & & & & & & & & & \\
\hline 4 & INTRA $^{\mathrm{b}}$ & -0.013 & -0.044 & 0.030 & 1.000 & & & & & & & & & & & \\
\hline 5 & INTER_MOD ${ }^{\mathrm{b}}$ & -0.010 & $-0.073^{*}$ & $0.086^{*}$ & -0.005 & 1.000 & & & & & & & & & & \\
\hline 6 & INTRA_MOD ${ }^{\mathrm{b}}$ & -0.054 & $-0.082^{*}$ & $0.049^{*}$ & $0.191^{*}$ & 0.039 & 1.000 & & & & & & & & & \\
\hline 7 & \begin{tabular}{|l} 
IT \\
Customization $^{\mathrm{b}}$
\end{tabular} & 0.052 & -0.035 & $0.196^{*}$ & $0.572^{*}$ & $0.130^{*}$ & $0.440^{*}$ & 1.000 & & & & & & & & \\
\hline 8 & \begin{tabular}{|l} 
IT \\
Infrastructure
\end{tabular} & -0.006 & $-0.073^{*}$ & 0.041 & $0.083^{*}$ & 0.029 & $0.202^{*}$ & $0.300^{*}$ & 1.000 & & & & & & & \\
\hline 9 & \begin{tabular}{|l} 
Supplier \\
Concentration
\end{tabular} & 0.017 & $0.164^{*}$ & -0.042 & -0.038 & $-0.077^{*}$ & $-0.157^{*}$ & -0.050 & $-0.107^{*}$ & 1.000 & & & & & & \\
\hline 10 & $\begin{array}{l}\text { Oil Crisis } \\
\text { Shock }\end{array}$ & -0.008 & -0.031 & 0.027 & -0.007 & 0.009 & $-0.062^{*}$ & -0.007 & -0.024 & $0.060^{*}$ & 1.000 & & & & & \\
\hline 11 & $\begin{array}{l}\text { Depreciation } \\
\text { Expenses }^{b}\end{array}$ & -0.034 & $-0.065^{*}$ & $0.220^{*}$ & $0.153^{*}$ & $0.248^{*}$ & $0.307^{*}$ & $0.281^{*}$ & $0.307^{*}$ & $-0.330^{*}$ & $-0.100^{\star}$ & 1.000 & & & & \\
\hline 12 & Firm Age ${ }^{b}$ & $0.124^{*}$ & $0.280^{*}$ & -0.006 & -0.024 & 0.000 & 0.046 & 0.036 & 0.043 & $0.080^{*}$ & 0.010 & $0.081^{*}$ & 1.000 & & & \\
\hline 13 & \begin{tabular}{|l}
$\begin{array}{l}\text { Production } \\
\text { Capacity }^{\mathrm{b}}\end{array}$ \\
\end{tabular} & -0.033 & $-0.246^{*}$ & $0.111^{*}$ & $0.171^{*}$ & $0.252^{*}$ & $0.257^{*}$ & $0.198^{*}$ & $0.235^{*}$ & $-0.296^{*}$ & -0.030 & $0.659^{\star}$ & 0.037 & 1.000 & & \\
\hline 14 & CWIP_Other ${ }^{b}$ & -0.029 & $-0.113^{*}$ & $0.191^{*}$ & $0.144^{*}$ & $0.208^{*}$ & $0.273^{*}$ & $0.206^{*}$ & $0.292^{\star}$ & $-0.284^{*}$ & 0.026 & $0.655^{\star}$ & 0.018 & $0.621^{*}$ & 1.000 & \\
\hline 15 & \begin{tabular}{|l} 
Deregulation \\
Shock
\end{tabular} & 0.001 & 0.029 & 0.015 & -0.008 & -0.027 & $-0.062^{*}$ & 0.010 & 0.005 & 0.032 & $0.800^{*}$ & $-0.062^{\star}$ & 0.009 & -0.033 & -0.026 & 1.000 \\
\hline
\end{tabular}

Notes: $\quad{ }^{a}$ These variables are mean centered.

${ }^{\mathrm{b}}$ These variables are standardized to z-scores.

${ }^{*} p<0.05$ 
depreciation expense using the reported depreciation in a year (Brynjolfsson and Hitt 2000); supplier concentration using the Herfindahl index, computed as total wholesale purchases by a firm from given suppliers in year $t$ over the total wholesale purchase in that year (Rai and Tang 2010); and firm location based on the eight region classification defined by the North American Electric Reliability Council (NERC 2011).

Industry Events: We measured deregulation shock using years elapsed since the 1996 FERC Orders 888/889, which represents a planned deregulatory shock with advance notice, and oil crisis shock using years elapsed since the 2001 oil crisis (popularly referred to as the Enron Crisis), which was an unplanned shock (Puller 2007).

\section{Analysis and Results}

\section{Descriptive Statistics}

We present the descriptive statistics in Table 3 and the correlations in Table 4. We observe that the variables of theoretical interest - that is, ROA, MSI, INTER, and INTRAexhibit reasonable variance. We also observe that INTER and MSI significantly and positively correlate with $\mathrm{ROA}_{\mathrm{t}+1}$.

\section{Analysis Procedure and Model Specifications}

We specify and estimate the following pooled OLS equations: ${ }^{10}$

$$
\begin{aligned}
& R O A_{i t+1}=\beta_{0}+\beta_{1} R O A_{i t}+\beta_{2} M S I_{i t}+\beta_{3} I_{N T E R_{i t}} \\
& +\beta_{4} \text { INTRA }_{i t}+\beta_{5} \text { Controls }_{i t}+\varepsilon_{i t} \\
& R O A_{i t+1}=\beta_{0}+\beta_{1} R O A_{i t}+\beta_{2} M S I_{i t}+\beta_{3} I N T E R_{i t} \\
& \beta_{4}{I N T R A_{i t}}+\beta_{5} \text { INTER }_{i t} \times \operatorname{MSI}_{i t}+\beta_{6} \text { INTRA }_{i t} \\
& \times M I_{i t}+\beta_{7} \text { Controls }_{i t}+\varepsilon_{i t}
\end{aligned}
$$

where subscript $i$ indicates firms, subscript $t$ indicates time, and $\varepsilon_{i t}$ is the error term associated with each firm-year observation. All independent variables are lagged by one year behind ROA to decrease the potential for endogeneity (Greene

\footnotetext{
${ }^{10} \mathrm{We}$ followed recommended procedures to evaluate if random effects (RE) or pooled OLS estimation is to be favored (Wooldridge 2002). We used the Breusch and Pagan Lagrangian multiplier test (the XTTEST0 command available in the Stata software package) to evaluate the null hypothesis that the coefficients estimated by the RE estimator are not systematically different than those estimated by the OLS estimator (Breusch and Pagan 1980). The test failed to reject the null hypothesis, supporting our use of pooled OLS estimation over RE estimation.
}

2000). Equation 2 includes the main effects of MSI, INTER, and INTRA and the control variables, and Equation 3 also includes the interactions between MSI and INTER/INTRA.

We specified a number of control variables. First, we controlled for the effects of previous $\mathrm{ROA}_{i t}{ }^{11}$ as firm performance can exhibit persistence and depend on the previous year's performance (Baum et al. 2000; Jacobson 1990). Second, we controlled for the following other IT investments: intrafirm IT modularization (INTRA_MOD) and interfirm IT modularization (INTER_MOD) as IT investments in relatively autonomous systems can provide flexibility and enable the development of higher-order capabilities, thereby affecting firm performance (Ethiraj and Levinthal 2004; Rai et al. 2012); IT customization as investments in idiosyncratic systems can be rare and hard to imitate, thereby being a source of value (Klein and Rai 2009); and IT infrastructure as investments in expanding a firm's digital infrastructure are capital-intensive and can be the basis for strategic capabilities and value creation (Aral and Weill 2007; Rai et al. 1997; Weill et al. 2002). Third, we controlled for the following firm characteristics: supplier concentration as a firm's performance can be influenced by the concentration of its supplier portfolio (Rai and Tang 2010); depreciation expense, firm age, production capacity, and non-IT capital work in process (CWIP_Other) as these variables can affect firm performance (Ang et al. 2000; Core et al. 2006), and firm location based on the NERC regional classification as industry clusters can affect firm performance (Dayasindhu 2002). Finally, we controlled for oil crisis shock, which was an unplanned shock (Puller 2007). ${ }^{12}$

In addition to including the above controls, we clustered to account for within-firm correlation due to the nonindependence of investments in a firm and used robust standard errors with correction for heteroskedasticity. Where necessary, we mean-centered variables to mitigate multicollinearity. All variance inflation factors and condition indices were well below their respective recommended thresholds of 10 and 30 (Greene 2007), with the highest variance inflation factor observed to be 4.69 and the largest condition index observed to be 18 .

\footnotetext{
${ }^{11}$ Results are robust when we use an average lagged performance of the last two or three years.

${ }^{12}$ Oil crisis shock and deregulation shock are highly correlated. Although we report results using oil crisis shock as a control variable, the results are robust to our using deregulation shock instead.
} 


\begin{tabular}{|c|c|c|}
\hline \multirow[b]{2}{*}{ Variables } & \multicolumn{2}{|c|}{ Dependent Variable $=$ ROA $_{t+1}$} \\
\hline & Main Effects Model & Interaction Effects Model \\
\hline \multirow{2}{*}{ ROA } & $0.577^{\star \star \star}$ & $0.582^{\star \star \star}$ \\
\hline & $(0.063)$ & $(0.062)$ \\
\hline \multirow{2}{*}{$\mathrm{MSI}^{\mathrm{a}}$} & -0.002 & -0.003 \\
\hline & $(0.002)$ & $(0.002)$ \\
\hline \multirow{2}{*}{ INTER $^{b}$} & $0.004^{\star \star \star}$ & $0.002^{\star \star \star}$ \\
\hline & $(0.001)$ & $(0.000)$ \\
\hline \multirow{2}{*}{ INTRA $^{b}$} & -0.001 & $-0.003^{\star \star}$ \\
\hline & $(0.001)$ & $(0.001)$ \\
\hline \multirow{2}{*}{$\mathrm{INTER}^{\mathrm{b}} \times \mathrm{MSI}^{\mathrm{a}}(\mathrm{H} 1+)$} & & $0.011^{\star * *}$ \\
\hline & & $(0.003)$ \\
\hline \multirow{2}{*}{$\mathrm{INTRA}^{\mathrm{b}} \times \mathrm{MSI}^{\mathrm{a}}(\mathrm{H} 2-)$} & & $-0.016^{\star *}$ \\
\hline & & $(0.008)$ \\
\hline \multirow{2}{*}{ INTER_MOD ${ }^{b}$} & 0.000 & 0.000 \\
\hline & $(0.000)$ & $(0.000)$ \\
\hline \multirow{2}{*}{ INTRA_MOD ${ }^{\mathrm{b}}$} & $-0.002^{* \star \star}$ & $-0.002^{\star \star \star}$ \\
\hline & $(0.001)$ & $(0.001)$ \\
\hline \multirow{2}{*}{ IT Customization ${ }^{\mathrm{b}}$} & $0.002^{* * *}$ & $0.002^{\star \star}$ \\
\hline & $(0.001)$ & $(0.001)$ \\
\hline \multirow{2}{*}{ IT Infrastructure ${ }^{b}$} & -0.001 & $-0.001^{\dagger}$ \\
\hline & $(0.001)$ & $(0.001)$ \\
\hline \multirow{2}{*}{ Supplier Concentration } & -0.004 & -0.004 \\
\hline & $(0.003)$ & $(0.003)$ \\
\hline \multirow{2}{*}{ Oil Crisis Shock } & $0.005^{\star \star \star}$ & $0.005^{\star \star \star}$ \\
\hline & $(0.001)$ & $(0.001)$ \\
\hline \multirow{2}{*}{ Depreciation Expense ${ }^{b}$} & 0.000 & 0.000 \\
\hline & $(0.001)$ & $(0.001)$ \\
\hline \multirow{2}{*}{ Firm Age A $^{\mathrm{b}, \mathrm{c}}$} & $0.001^{\dagger}$ & $0.001^{\dagger}$ \\
\hline & $(0.001)$ & $(0.001)$ \\
\hline \multirow{2}{*}{ Production Capacity ${ }^{b, d}$} & 0.000 & 0.000 \\
\hline & $(0.001)$ & $(0.001)$ \\
\hline \multirow{2}{*}{ CWIP_Otherb } & -0.001 & -0.001 \\
\hline & $(0.001)$ & $(0.001)$ \\
\hline \multirow[b]{2}{*}{ Constant } & $0.022^{\star \star \star}$ & $0.022^{\star \star \star}$ \\
\hline & $(0.003)$ & $(0.003)$ \\
\hline$R^{2}$ & $0.315^{\star \star \star}$ & $0.332^{* * *}$ \\
\hline$\Delta R^{2}$ & & $0.017^{\star \star *}$ \\
\hline Firm & 133 & 133 \\
\hline Firm-Year Observations & 886 & 886 \\
\hline
\end{tabular}

Notes: Unstandardized coefficients reported. Standard errors are in parentheses, and are robust and clustered at the firm level. NERC region dummies included as controls.

${ }^{*} p<0.10,{ }^{* *} p<0.05,{ }^{* * *} p<0.01$

${ }^{\dagger}$ Effects are significant at $p<0.10$; coefficients and standard errors shown have been rounded.

${ }^{a}$ These variables are mean centered.

${ }^{\mathrm{b}}$ These variables are standardized to $\mathrm{z}$-scores.

${ }^{\circ} 0$ replaced by 0.1 to be able to take the log.

${ }^{d}$ Winsorized at $5 \%$ tails; results stable without winsorizing. 


\section{Results}

We present the pooled OLS estimation results in Table 5. In the main effects model, we find INTER to be positively associated with $\operatorname{ROA}_{t+1}(\beta=0.004, p<0.01)$. In the interaction effects model, we find a positive effect of INTER $\times$ MSI on $\mathrm{ROA}_{\mathrm{t}+1}(\beta=0.011, \mathrm{p}<0.01)$, supporting $\mathrm{H} 1$, and a negative effect of INTRA $\times$ MSI on $\operatorname{ROA}_{t+1}(\beta=-0.016, p<0.05)$, supporting $\mathrm{H} 2$.

\section{Interaction Plots and Economic Significance}

To better understand the (mis)fit relationships, we followed Aiken and West's (1991) recommendation and plotted the significant interactions (see Figure 3). We observe increases in INTER positively impact ROA $_{t+1}$ when MSI is high (Figure $3 \mathrm{a})$. When firm $i$ in year $t$ is one standard deviation above the industry mean in its investments to develop interfirm process integration capability (i.e., $\mathrm{z}=1$ for INTER) and increases reliance in that year by 10 percent on the wholesale market for electricity it sells to customers (i.e., 0.1 increase in MSI), then in the next year it realizes a 0.11 percent increase in $\operatorname{ROA}(\beta \times$ INTER $\times$ MSI $=0.011 \times 1 \times 0.1=0.0011)$. In contrast, we observe that increases in INTRAdecrease ROA $_{t+1}$ to a greater extent when MSI is high than when it is low (Figure $3 \mathrm{~b}$ ). When firm $i$ in year $t$ is one standard deviation above the industry mean in its investments to develop intrafirm process integration capability (i.e., $z=1$ for INTRA) and increases reliance in that year by 10 percent on the wholesale market for electricity that it sells to customers (i.e., 0.1 increase in $\mathrm{MSI})$, then in the next year it realizes a 0.16 percent decrease in $\mathrm{ROA}(\beta \times \mathrm{INTRA} \times \mathrm{MSI}=-0.016 \times 1 \times$ $0.1=-0.0016)$.

\section{Robustness Tests}

Fixed and Random Effects Estimations: We evaluated the robustness of the pooled OLS estimation results using fixed effects (FE) and random effects (RE) estimations and found the results to be robust. The results for the $\mathrm{FE}$ and $\mathrm{RE}$ estimations are provided in Appendix A.

Endogeneity Test for MSI: In addition to lagging forward ROA to mitigate endogeneity concerns and evaluating the robustness of the OLS estimations using FE estimation, we evaluated if MSI was endogenous using the XTIVREG2 twostep GMM procedure in Stata (Schaffer 2005). We identified the following three instruments for MSI: deregulation shock, $\log$ of the total number of production plants for a firm lagged one year (Log of Total Plants $\left.\mathrm{t}_{\mathrm{t}-1}\right)$, and investments in modular interfirm systems of the firm lagged one year $\left(\right.$ INTER_MOD $\left.{ }_{t-1}\right)$. These instruments satisfy the prerequisites of being relevant theoretically and exogenous (Greene 2007). The results indicate that MSI is not endogenous $(p>0.07)$, the overidentifying restriction is satisfied (Hasen $\mathrm{J}=0.12, \mathrm{p}>$ 0.9 ), and the instruments are strong (partial R-squared $=0.12$, joint significance of instruments F-statistic $=12.39, \mathrm{p}<$ 0.001 ) and valid (Anderson-Rubin Wald F-statistic $=0.06$, p > 0.9) (Anderson and Rubin 1949). See Appendix B for details.

Additional Firm Performance Measures: We evaluated the effects of the interactions between MSI and the development of the IT-enabled process integration capabilities on two other firm performance measures: Tobin's $\mathrm{Q}_{\mathrm{t}+1}$ and operating revenue/total assets $_{t+1}$. These measures capture market valuation and operational performance, respectively, and have been used in IT business value studies (e.g., Bharadwaj 2000; Bharadwaj et al. 1999; Santhanam and Hartono 2003; Tanriverdi et al. 2007). We find support for H1 using both Tobin's $\mathrm{Q}_{\mathrm{t}+1}$ and operating revenue/total assets ${ }_{\mathrm{t}+1}$ but do not find support for $\mathrm{H} 2$ with these additional performance measures. The results for these estimations are provided in Appendix A.

Summary of Results: Table 6 provides a summary of the pooled OLS results with ROA as the measure of firm performance, the robustness results with ROA as the measure of firm performance and using $\mathrm{FE}$ and RE estimations, and the robustness results with Tobin's $\mathrm{Q}$ and operating revenue/total assets as additional measures of firm performance. We find $\mathrm{H} 1$ and $\mathrm{H} 2$ to be supported for all ROA models, and $\mathrm{H} 1$ to be also supported for the Tobin's Q and operating revenue/total assets models.

Winsorized Analysis: As firm performance can have extreme values, we winsorized the top and bottom 20 observations ${ }^{13}$ (Kaplan and Zingales 1997). All results were robust to winsorizing the dependent variables.

\section{Discussion}

Our findings in the EUI context support our hypotheses that fit between the development of interfirm process integration capability and increases in MSI accrues performance benefits and misfit between the development of intrafirm process integration capability and increases in MSI extracts performance penalties. Our results have implications for our understanding about the creation of business value from investments in ITenabled process integration capabilities and the management of plural sourcing.

\footnotetext{
${ }^{13}$ We replaced the 20 highest and lowest values of the dependent variables by the next value counting inward from the extremes (Barnett and Lewis 1994).
} 


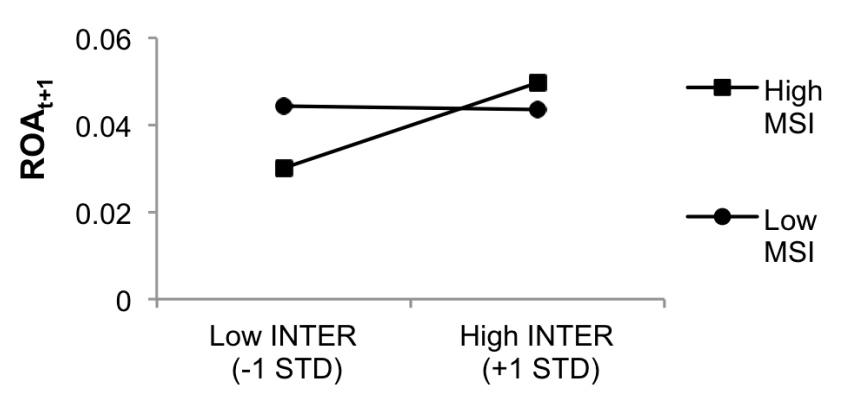

Figure 3a. Interaction Effect of INTER and MSI

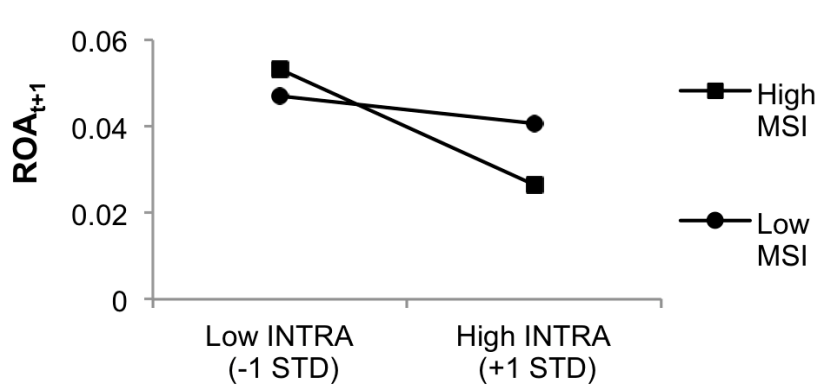

Figure 3a. Interaction Effect of INTRA and MSI

\section{Figure 3. Interaction Effects}

\section{Table 6. Summary of Results}

\begin{tabular}{|c|c|c|c|c|c|}
\hline & $\begin{array}{c}\text { Primary } \\
\text { Test }\end{array}$ & \multicolumn{4}{|c|}{ Robustness Tests } \\
\hline Firm Performance $\rightarrow$ & $\mathrm{ROA}_{\mathrm{t}+1}$ & \multicolumn{2}{|c|}{$\mathrm{ROA}_{\mathrm{t}+1}$} & Tobin's $Q_{t+1}$ & Oper. Rev/Assets ${ }_{t+1}$ \\
\hline Estimation Method $\rightarrow$ & OLS & FE & RE & FE & OLS \\
\hline $\mathrm{H} 1:$ INTER $\times \mathrm{MSI}(+)$ & $(+) \mathrm{S}$ & $(+) \mathrm{S}$ & $(+) \mathrm{S}$ & $(+) S$ & $(+) S$ \\
\hline H2: INTRA $\times$ MSI (-) & $(-) S$ & $(-) S$ & $(-) S$ & $(+) \mathrm{NS}$ & $(+) \mathrm{NS}$ \\
\hline FE favored to RE? & No & & & Yes & No \\
\hline RE favored to Pooled OLS? & No & & & Yes & No \\
\hline Conclusion & \multicolumn{3}{|c|}{ Support for $\mathrm{H} 1$ \& $\mathrm{H} 2$} & Support for $\mathrm{H} 1$ & Support for $\mathrm{H} 1$ \\
\hline
\end{tabular}

Notes: $\quad \mathrm{S}$ indicates a significant coefficient, NS indicates a nonsignificant coefficient.

Coefficient signs shown in parentheses.

\section{Theoretical Implications}

By surfacing how the interdependencies between investments in IT-enabled process integration capabilities and plural sourcing can either create or erode business value, we contribute to the IT business value and IT capabilities literatures (e.g., Bharadwaj 2000; Bharadwaj et al. 1999; Bharadwaj et al. 2007; Brynjolfsson and Hitt 2000; Mithas et al. 2012; Mithas et al. 2013; Rai et al. 2006; Rai and Tang 2010). Additionally, by showing that firm performance is impacted by the interaction of IT-enabled process integration capabilities and plural sourcing, we contribute to our understanding of the complementary roles of the TCE and the capabilities perspectives in explaining firm performance. We elaborate on these theoretical contributions below.

We extend past work that has shown IT-enabled interfirm process integration capability creates business value (Barua et al. 2004; Bharadwaj et al. 2007; Rai et al. 2006) by surfacing that gains in firm performance from investing in this capability are contingent on plural sourcing, or a firm's reliance on the market relative to internal production (Heide 2003; Parmigiani 2007). Our results reveal that a firm realizes gains in ROA when it complements increases in investments to develop interfirm process integration capability with increases in MSI (Figure 3a). Our robustness tests with additional firm performance measures also reveal that a firm realizes gains in both Tobin's $Q$ and operating revenue/ total assets when it complements increases in investments to develop interfirm process integration capability with increases in MSI. When a firm invests in developing IT-enabled interfirm process integration capability, it allocates scarce resources to observe consumption and predict demand at granular levels (e.g., individual customers or customer microsegments) and to align supply with demand by dynamically sourcing from markets. Our results show that these IT investments create greater business value-assessed in terms of profitability, market valuation, and asset turnover-for a firm when its plural sourcing choices make the role of coordinating transactions in the market more salient relative to internal production. 
Our study also reveals that when a firm reduces internal production relative to market sourcing, its investments in developing intrafirm coordination IT capability exact penalties in business value. Specifically, we find a firm's investments in developing intrafirm process integration capability to negatively impact ROA when it increases reliance on sourcing from the market relative to internal production (Figure $3 b$ ). When a firm increases sourcing from the market relative to internal production, it reduces the value-creating role of the firm's hierarchy and authority to coordinate internal production relative to the value-creating role of the firm's capabilities to coordinate transactions in the market. As such, a sourcing decision to increase reliance on the market relative to internal production is inconsistent with the decision to invest in developing IT-enabled intrafirm process integration capability, and leads to a reduction in firm profitability. This finding contributes to the emerging understanding on how a firm's IT-enabled intrafirm process integration initiatives together with its other strategic choices affect different aspects of business value creation. In our robustness tests using additional firm performance measures, we did not detect a firm realizing a market valuation penalty for the misfit between developing intrafirm process integration capability and increasing emphasis on the market relative to internal production. A firm may not be penalized in market valuation for this misalignment in a given time period because of the expectation that the level of reliance on internal production relative to the market can increase in future time periods. We also did not detect a decline in operating revenue/total assets, conceivably because price controls and asset-intensive internal production in the EUI mitigate the adverse effects of misalignment between IT investments in process integration and plural sourcing decisions. As such, a firm's development of IT-enabled process integration capability to organize production internally (e.g., control and coordinate its distributed production assets) is a mismatch with its increased reliance on the market relative to internal production to fulfill demand, and this mismatch exacts a penalty with respect to the firm's profitability.

Collectively, our findings reveal how explanations of firm capabilities for IT-enabled process integration and TCE for plural sourcing interact to explain firm performance. Integrating the viewpoints that internal costs of organizing production and transaction costs need to be considered in making governance choices (Masten et al. 1991) and a firm's capabilities and governance choices are interdependent (Jacobides and Winter 2005; Madhok 2002; Poppo and Zenger 1998), we show that the business value of a firm's investments in developing IT-enabled process integration capabilities is influenced by fit and misfit with the firm's plural sourcing strategy. Our findings support Williamson's (1999) observation that an integrated perspective of firm competencies and TCE provides a more complete explanation of how to organize transactions effectively than either the firm competencies or TCE perspectives individually. In sum, our study elaborates the theoretical explanations on how IT creates business value from a capabilities perspective, with a focus on how IT resources and capabilities can be effectively combined with non-IT resources and capabilities (Aral and Weill 2007; Bharadwaj et al. 2007; Tambe et al. 2012), to an integrated capabilities-governance perspective, with a focus on the discriminating alignment between capabilities and governance of transactions.

\section{Implications for Practice}

Our study suggests that IT executives and sourcing managers can collaborate to create synergies between investments in ITenabled process integration capabilities and plural sourcing choices. They need to recognize that the business value a firm can extract from its IT investments in process integration is a function of its reliance on the market relative to internal production for the sourcing of goods/services. Consequently, they need to establish collaborative processes to dynamically align decisions to invest in IT-enabled process integration systems and to engage in the plural sourcing of goods/ services.

Given the potential to leverage advances in IT to innovate how a firm organizes internal production of a good/service and how it transacts in the market for the good/service, IT executives need to allocate IT investments in innovating these processes while considering the sourcing choices of their firms. They need to recognize that there are significant consequences to the fit or misfit between IT investments in developing process integration capabilities and MSI. On the one hand, IT investments in developing interfirm process integration capability while increasing MSI are likely to increase firm profitability, market valuation and asset turnover. On the other hand, IT investments in developing intrafirm IT capabilities while increasing MSI are likely to extract penalties in firm profitability. By coordinating IT investment and sourcing decisions, IT executives can create business value and avoid performance penalties from IT investments directed at innovating interfirm and intrafirm processes.

\section{Limitations and Future Research}

Our focus on the EUI enabled us to mitigate confounds due to cross-industry differences (e.g., electricity is a homogeneous product), define a context-appropriate measure of MSI, obtain granular data on actual IT investments that were reported to 
federal agencies and code them based on the characteristics of the technology, isolate regulatory and unplanned shocks, and create a rich panel dataset on MSI, development of IT-enabled process integration capabilities, firm performance, and a range of control variables at the industry, regional, and firm levels. Although these features provide a strong basis for confidence in our results, we recognize that our coding scheme, while carefully developed and extensively validated, is subject to the limitation of the level of description that is provided by firms in their FERC filings. Future research, which uses primary and archival data on sourcing choices and types of IT investments to develop IT capabilities across industry contexts, can evaluate the robustness of our findings and their generalizability to other contexts.

As the EUI is characterized by high intensity of capital assets, caution should be exercised in extrapolating the findings outside of comparable asset-intensive industries (e.g., airlines, military complexes, logistics, and transportation). Although the EUI has witnessed major deregulation, it is regulated on some important competitive parameters (e.g., prices, market reach, service reliability, scope of transactions for firms in power generation, transmission, and distribution). Moreover, electricity is the perfect commodity that cannot be easily inventoried. Consequently, for electric utility firms in the power-generation segment, increasing MSI requires the ability to dynamically coordinate supply with demand. Accordingly, we conceptualized customer-facing systems for demand management and supplier-facing systems for supply management as constitutive elements of an overall IT-enabled interfirm process integration capability and examined its fit with MSI. Future research can relax the regulatory and product conditions that characterize the EUI, conceptualize a corresponding set of more granular interfirm IT capabilities (e.g., distribution-facing and supplier-facing) for these other contexts, and examine the (mis)alignment between these interfirm IT capabilities and plural sourcing choices. It can also examine the relative importance of IT-enabled supply-side process integration capability and IT-enabled customer-side process integration capability when demand and supply do not need to be aligned as responsively as is required in the EUI context. Finally, future research can examine how the formulation and enactment of decisions pertaining to sourcing of goods/services and investments in IT process integration coevolve and the resulting performance consequences.

\section{Conclusion}

Our study, situated in the EUI, unpacks the performance consequences of a firm achieving discriminating alignment between IT-enabled process integration capabilities and MSI, or the extent of reliance on the market relative to internal production for sourcing a good/service. When a firm achieves fit by developing IT-enabled interfirm process integration capability and increasing MSI, it creates business value by increasing profitability, market valuation, and asset turnover. In contrast, when a firm falls into misfit by developing ITenabled intrafirm process integration capability and increasing MSI, it loses business value by incurring penalties in profitability. Our study reveals that IT business value is better understood through an integrated capabilities-governance perspective than through a capabilities or governance perspective in isolation. We hope our study will stimulate exploration of how the interdependence of specific IT capabilities and governance choices influences accounting-based and market-based measures of firm performance in different product-market and regulatory contexts.

\section{Acknowledgments}

We appreciate the constructive comments provided to us by the senior editor, associate editor, and the reviewers. We thank the conformity officers, plant engineers, and IT executives at the utility firms for participating in the validation of our coding of the IT investment data. We also thank the attendees at the colloquium presentations at McGill University, University of Memphis, University of Texas at Dallas, Queensland University of Technology, and Temple University for their constructive comments on earlier versions of this paper.

\section{References}

Aiken, L. S., and West, S. G. 1991. Multiple Regression: Testing and Interpreting Interactions, London: Sage Publications.

Anderson, T., and Rubin, H. 1949. "Estimation of the Parameters of a Single Equation in a Complete System of Stochastic Equations," The Annals of Mathematical Statistics (20:1), pp. 46-63.

Ang, J., Cole, R., and Lin, J. W. 2000. "Agency Costs and Ownership Structure," The Journal of Finance (55:1), pp. 81-106.

Aral, S., and Weill, P. 2007. "IT Assets, Organizational Capabilities, and Firm Performance: How Resource Allocations and Organizational Differences Explain Performance Variation," Organization Science (18:5), pp. 763-780.

Argyres, N. 1999. "The Impact of Information Technology on Coordination: Evidence from the B-2 'Stealth' Bomber," Organization Science (10:2), pp. 162-180.

Argyres, N. 2011. "Using Organizational Economics to Study Organizational Capability Development and Strategy," Organization Science (22:5), pp. 1138-1143.

Bala, H., and Venkatesh, V. 2007. "Assimilation of Interorganizational Business Process Standards," Information Systems Research (18:3), pp. 340-363.

Baldwin, C. Y. 2008. "Where Do Transactions Come From? Modularity, Transactions, and the Boundaries of Firms," Industrial \& Corporate Change (17:1), pp. 155-195. 
Bardhan, I., Whitaker, J., and Mithas, S. 2006. "Information Technology, Production Process Outsourcing, and Manufacturing Plant Performance," Journal of Management Information Systems (23:2), pp. 13-40.

Barki, H., and Pinsonneault, A. 2005. "A Model of Organizational Integration, Implementation Effort, and Performance," Organization Science (16:2), pp. 165-179.

Barnett, V., and Lewis, T. 1994. Outliers in Statistical Data (3 $3^{\text {rd }}$ ed.), New York: Wiley.

Barua, A., Konana, P., Whinston, A., and Yin, F. 2004. "An Empirical Investigation of Net-Enabled Business Value: An Exploratory Investigation," MIS Quarterly (28:4), pp. 585-620.

Baum, J., Calabrese, T., and Silverman, B. 2000. "Don't Go It Alone: Alliance Network Composition and Startups' Performance in Canadian Biotechnology," Strategic Management Journal (21:3), pp. 267-294.

Bharadwaj, A. S. 2000. "A Resource-Based Perspective on Information Technology Capability and Firm Performance: An Empirical Investigation," MIS Quarterly (24:1), pp. 169-196.

Bharadwaj, A. S., Bharadwaj, S. G., and Konsynski, B. R. 1999. "Information Technology Effects on Firm Performance as Measured by Tobin's Q," Management Science (45:7), pp. 1008-1024.

Bharadwaj, S., Bharadwaj, A., and Bendoly, E. 2007. "The Performance Effects of Complementarities Between Information Systems, Marketing, Manufacturing, and Supply Chain Processes," Information Systems Research (18:4), pp. 437-453.

Boone, M., and Hackeny, C. 2009. "Houston Brings its Grid into the Digital Age," Trade \& Distribution (61:12), pp. 36-39.

Breusch, T., and Pagan, A. 1980. "The Lagrange Multiplier Test and its Applications to Model Specifications in Econometrics," The Review of Economic Studies (47:1), pp. 239-253.

Brynjolfsson, E., and Hitt, L. M. 2000. "Beyond Computation: Information Technology, Organizational Transformation and Business Performance," The Journal of Economic Perspectives (14:4), pp. 23-48.

Choudhury, V., Hartzel, K. S., and Konsynski, B. R. 1998. "Uses and Consequences of Electronic Markets: An Empirical Investigation in the Aircraft Parts Industry," MIS Quarterly (22:4), pp. 471-507.

CIA. 2011. "CIA World Factbook," https:/www.cia.gov/ library/publications/the-world-factbook/geos/us.html; accessed May 2, 2011.

Core, J., Guay, W., and Rusticus, T. 2006. "Does Weak Governance Cause Weak Stock Returns? An Examination of Firm Operating Performance and Investors' Expectations," The Journal of Finance (61:2), pp. 655-687.

Dayasindhu, N. 2002. "Embeddedness, Knowledge Transfer, Industry Clusters and Global Competitiveness: A Case Study of the Indian Software Industry," Technovation (22:9), pp. 551-560.

Ethiraj, S., and Levinthal, D. 2004. "Modularity and Innovation in Complex Systems," Management Science (50:2), pp. 159-173.

Gattiker, T. F., and Goodhue, D. L. 2005. "What Happens After ERP Implementation: Understanding the Impact of Interdependence and Differentiation on Plant-Level Outcomes," MIS Quarterly (29:3), pp. 559-585.
Grant, R. 1996. "Toward a Knowledge Based Theory of the Firm," Strategic Management Journal (17:S2), pp. 109-122.

Greene, W. 2007. Econometric Analysis (6 $6^{\text {th }}$ ed.), Upper Saddle River, NJ: Prentice Hall.

Gulati, R., Lawrence, P., and Puranam, P. 2005. "Adaptation in Vertical Relationships: Beyond Incentive Conflict," Strategic Management Journal (26:5), pp. 415-440.

Heide, J. 2003. "Plural Governance in Industrial Purchasing," The Journal of Marketing (67:4), pp. 18-29.

Jacobides, M., and Billinger, S. 2006. "Designing the Boundaries of the Firm: From 'Make, Buy, or Ally' to the Dynamic Benefits of Vertical Architecture," Organization Science (17:2), pp. 249-261.

Jacobides, M., and Hitt, L. M. 2005. "Losing Sight of the Forest for the Trees? Productive Capabilites and Gains from Trade as Drivers of Vertical Scope," Strategic Management Journal (26:13), pp. 1209-1227.

Jacobides, M., and Winter, S. 2005. "The Co-Evolution of Capabilities and Transaction Costs: Explaining the Institutional Structure of Production “ Strategic Management Journal (26:5), pp. 395-413.

Jacobson, R. 1990. "Unobservable Effects and Business Performance," Marketing Science (9:1), pp. 74-85.

Joskow, P. 1989. "Regulatory Failure, Regulatory Reform, and Structural Change in the Electrical Power Industry," Brookings Papers on Economic Activity. Microeconomics, pp. 125-208.

Kaplan, S. N., and Zingales, L. 1997. "Do Investment-Cash Flow Sensitivities Provide Useful Measures of Financing Constraints?," Quarterly Journal of Economics (112:1), pp. 169-215.

Khanna, T., Gulati, R., and Nohria, N. 1998. "The Dynamics of Learning Alliances: Competition, Cooperation, and Relative Scope," Strategic Management Journal (19:3), pp. 193-210.

Klein, R., and Rai, A. 2009. "Interfirm Strategic Information Flows in Logistics Supply Chain Relationships," MIS Quarterly (33:4), pp. 735-762.

$\mathrm{Ku}$, A. 2000. “Online Power Trading," analyticalQ (http://www. analyticalq. com/energy/online/).

Langlois, R. 1992. "Transaction-Cost Economics in Real Time," Industrial and Corporate Change (1:1), pp. 99-127.

Leiblein, M., and Miller, D. 2003. "An Empirical Examination of Transaction- and Firm-Level Influences on the Vertical Boundary of the Firm," Strategic Management Journal (24:9), pp. 839-859.

Lieberman, M. B. 1984. "The Learning Curve and Pricing in the Chemical Processing Industries," The RAND Journal of Economics (15:2), pp. 213-228.

Liggett, W., McNerney, R., and Hankey, R. 2000. "The Changing Structure of the Electric Power Industry 2000: An Update," DOE/EIA-0562(00), U.S. Energy Information Administration, Washington, DC, pp. 1-154.

Madhok, A. 2002. "Reassessing the Fundamentals and Beyond: Ronald Coase, The Transaction Cost and Resource-Based Theories of the Firm and the Institutional Structure of Production," Strategic Management Journal (23:6), pp. 535-550.

Malhotra, A., Gosain, S., and El-Sawy, O. 2005. "Absorptive Capacity Configurations in Supply Chains: Gearing for PartnerEnabled Market Knowledge Creation," MIS Quarterly (29:1), pp. 145-187. 
Mani, D., Barua, A., and Whinston, A. 2010. "An Empirical Analysis of the Impact of Information Capabilities Design on Business Process Outsourcing Performance," MIS Quarterly (34:1), pp. 39-62.

Mani, D., Barua, A., and Whinston, A. 2011. “An Empirical Analysis of the Contractural and Information Structures of Business Process Outsourcing Relationships," Information Systems Research (23:3), pp. 618-634.

Markus, M. L., and Robey, D. 1988. "Information Technology and Organizational Change: Causal Structure in Theory and Research," Management Science (34:5), pp. 583-598.

Masten, S., Meehan, J., and Snyder, E. 1991. "The Cost of Organization," Journal of Law, Economics, and Organization (7:1), pp. $1-25$.

Melville, N., Kraemer, K., and Gurbaxani, V. 2004. "Information Technology and Organizational Performance: An Integrative Model of IT Business Value," MIS Quarterly (28:2), pp. 283-322.

Mishra, A., Devaraj, S., and Vaidyanathan, G. 2013. "Capability Hierarchy in Electronic Procurement and Procurement Process Performance: An Empirical Analysis," Journal of Operations Management (31:6), pp. 376-390.

Mithas, S., Tafti, A., Bardhan, I., and Goh, J. M. 2012. "Information Technology and Firm Profitability: Mechanisms and Emprical Evidence," MIS Quarterly (36:1), pp. 205-224.

Mithas, S., Tafti, A., and Mitchell, W. 2013. "How a Firm's Competitive Environment and Digital Strategic Posture Influence Digital Business Strategy," MIS Quarterly (37:2), pp. 511-536.

Mithas, S., and Whitaker, J. 2007. "Is the World Flat or Spiky? Information Intensity, Skills, and Global Service Disaggregation," Information Systems Research (18:3), pp. 237-259.

Monteverde, K., and Teece, D. 1982. "Supplier Switching Costs and Vertical Integration in the Automobile Industry," The Bell Journal of Economics (13:1), pp. 206-213.

Morris, M. G., and Venkatesh, V. 2010. "Job Characteristics and Job Satisfaction: Understanding the Role of Enterprise Resource Planning System Implementation," MIS Quarterly (34:1), pp. 143-161.

NERC. 2011. "Regional Entities," North American Electric Reliability Corporation (http://www.nerc.com/About NERC/; accessed May 2011).

Neuendorf, K. 2002. The Content Analysis Guidebook, Thousand Oaks, CA: Sage Publications.

Nickerson, J., and Zenger, T. 2002. "Being Efficiently Fickle: A Dynamic Theory of Organizational Choice," Organization Science (13:5), pp. 547-566.

Parmigiani, A. 2007. "Why Do Firms Both Make and Buy? An Investigation of Concurrent Sourcing," Strategic Management Journal (28:3), pp. 285-311.

Polk, C. 2001. "Electricity Trading: Resolving The Electricity Paradox," Global Energy Business (September/October), pp. 16-20.

Poppo, L., and Zenger, T. 1998. "Testing Alternative Theories of the Firm: Transaction Cost, Knowledge-Based, and Measurement," Strategic Management Journal (19:9), pp. 853-877.
Puller, S. L. 2007. "Pricing and Firm Conduct in California's Deregulated Electricity Market," Review of Economics \& Statistics (89:1), pp. 75-87.

Puranam, P., Gulati, R., and Bhattacharya, S. 2013. "How Much to Make and How Much to Buy? An Analysis of Optimal Plural Sourcing Strategies," Strategic Management Journal (34:10), pp. 1145-1161.

Rai, A., Patnayakuni, R., and Patnayakuni, N. 1997. "Technology Investment and Business Performance," Communications of the ACM (40:7), pp. 89-97.

Rai, A., Patnayakuni, R., and Seth, N. 2006. "Firm Performance Impacts of Digitally Enabled Supply Chain Integration Capabilities," MIS Quarterly (30:2), pp. 225-246.

Rai, A., Pavlou, P., Im, G., and Du, S. 2012. "Interfirm IT Capabilities and Communications for Cocreating Relational Value: Evidence from the Logistics Industry," MIS Quarterly (36:1), pp. 233-262.

Rai, A., and Tang, X. 2010. "Leveraging IT Capabilities and Competitive Process Capabilities for the Management of Interorganizational Relationship Portfolios," Information Systems Research (21:3), pp. 516-542.

Ranganathan, C., and Brown, C. 2006. "ERP Investments and the Market Value of Firms: Toward an Understanding of Influential ERP Project Variables,” Information Systems Research (17:2), pp. 145-161.

Ray, G., Muhanna, W. A., and Barney, J. B. 2005. "Information Technology and the Performance of the Customer Service Process: A Resource-Based Analysis," MIS Quarterly (29:4), pp. 625-652.

Repice, R., Adler, R., Berry, J., Michaels, J., Grape, S., Paduano, N., Bonnar, D., Namovicz, C., Barrick, J., Anderson, M., Sweeney, A., Young, P., Wirman, C., Mobilia, M., Bredehoeft, G., Lindstrom, P., and Ko, N. 2012. "Annual Energy Review 2011," DOE/EIA-0384, U.S. Energy Information Administration, Washington, DC, pp. 1-370.

Robey, D., Im, G., and Wareham, J. 2008. "Theoretical Foundations of Empirical Research on Interorganizational Systems: Assessing Past Contributions and Guiding Future Directions," Journal of the Association for Information Systems (9:9), pp. 497-518.

Ross, J. W. 2003. "Creating a Strategic IT Architecture Competency: Learning in Stages," Working Paper No. 4314-03, Sloan School of Management, Massachusetts Institute of Technology.

Ross, J. W., Weill, P., and Roberston, D. 2006. Enterprise Architecture as Strategy, Boston: Harvard Business School Press.

Santhanam, R., and Hartono, E. 2003. "Issues in Linking Information Technology Capability to Firm Performance," MIS Quarterly (27:1), pp. 125-153.

Saraf, N., Langdon, C. S., and Gosain, S. 2007. "IS Application Capabilities and Relational Value in Interfirm Partnerships," Information Systems Research (18:3), pp. 320-339.

Schaffer, M. 2005. "XTIVREG2: Stata Module to Perform Extended IV/2SLS, GMM and AC/HAC, LIML and K-Class 
Regression for Panel Data Models," Statistical Software Components S4254010, Department of Economics, Boston College.

Soh, C., Markus, M. L., and Goh, K. H. G. 2006. "Electronic Marketplaces and Price Transparency: Strategy, Information Technology, and Success," MIS Quarterly (30:3), pp. 705-723.

SourceOne. 2014. "Vineland Municipal Electric Utility Enhances Energy Security, Reliability and Grid Modernization with SourceOne's Expertise," Press Release, SourceOne (http://www. sourceone-energy.com/news/press-releases/bid/186140/VinelandMunicipal-Electric-Utility-enhances-energy-security-reliabilityand-grid-modernization-with-SourceOne-s-expertise; accessed October 20, 2014).

Steensma, K., and Corley, K. 2001. “Organizational Context as a Moderator of Theories on Firm Boundaries for Technology Sourcing," Academy of Management Journal (44:2), pp. 271-291.

Subramani, M. R., and Venkatraman, N. 2003. "Safeguarding Investments in Asymmetric Interoganizational Relationships: Theory and Evidence," Academy of Management Journal (46:1), pp. 46-62.

Sutcliffe, K., and Zaheer, A. 1998. "Uncertainty in the Transaction Environment: An Empirical Test," Strategic Management Journal (19:1), pp. 1-23.

Tallon, P., and Pinsonneault, A. 2011. "Competing Perspectives on the Link Between Strategic Information Technology Alignment and Organizational Agility: Insights from a Mediation Model," MIS Quarterly (35:2), pp. 463-486.

Tambe, P., Hitt, L. M., and Brynjolfsson, E. 2012. "The Extroverted Firm: How External Information Practices Affect Innovation and Productivity," Management Science (58:5), pp. 843-859.

Tanriverdi, H., Konana, P., and Ling, G. 2007. "The Choice of Sourcing Mechanisms for Business Processes," Information Systems Research (18:3), pp. 280-299.

Taylor, M. J., and Fuller, L. C. 1986. "Coal-Fired Electric Power Plant Life Extension: An Overview," Oak Ridge National Laboratory, Oak Ridge, TN.

Tiwana, A. 2008. "Does Technological Modularity Substitute for Control? A Study of Alliance Performance in Software Outsourcing," Strategic Management Journal (29:7), pp. 769-780.

Venkatraman, N. 1989. "The Concept of Fit in Strategy Research: Toward Verbal and Statistical Correspondence," The Academy of Management Review (14:3), pp. 423-444.

Weill, P., Subramani, M. R., and Broadbent, M. 2002. "Building IT Infrastructure for Strategic Agility," MIT Sloan Management Review (44:1), pp. 57-65.

Williamson, O. E. 1975. Markets and Hierarchies, New York: Free Press.

Williamson, O. E. 1985. The Economic Institutions of Capitalism: Firms, Markets, Relational Contracting, New York: Free Press.

Williamson, O. E. 1991. "Comparative Economic Organization: The Analysis of Discrete Structural Alternatives," Administrative Science Quarterly (36:2), pp. 269-296.
Williamson, O. E. 1999. "Strategy Research: Governance and Competence Perspectives," Strategic Management Journal (20:12), pp. 1087-1108.

Wooldridge, J. 2002. Econometric Analysis of Cross Section and Panel Data, Cambridge, M:A: MIT Press.

\section{About the Authors}

Arun Rai is Regents' Professor of the University System of Georgia, J. Mack Robinson Chair of IT-Enabled Process Innovation and Supply Chains, and Harkins Chair of Information Systems at the Robinson College of Business, Georgia State University. His research has examined how firms can leverage information technologies in their strategies, interfirm relationships, and processes, and how systems can be successfully developed and implemented. His articles have appeared in MIS Quarterly, Information Systems Research, Management Science, Journal of Management Information Systems, Journal of Operations Management and other journals. He serves, or has served, as a senior editor for MIS Quarterly, Information Systems Research, and Journal of Strategic Information Systems and as an associate editor for MIS Quarterly, Information Systems Research, Management Science, and Journal of MIS. He was named Fellow of the Association for Information Systems in 2010 and Distinguished Fellow of the INFORMS Information Systems Society in 2014.

Ilgaz Arikan is an assistant professor of Management and Information Systems at Kent State University. He received his Ph.D. from the Ohio State University. His research has been interdisciplinary with an emphasis on how firms create and sustain competitive advantage in various contexts. In the field of Information Systems, he studies IT-enabled business models, firms' strategies, and the governance of IT resources and capabilities. His work has spanned country, network, firm, team, and individual levels of analyses.

Jessica Pye is a Ph.D. candidate in the Center for Process Innovation, Robinson College of Business at Georgia State University. She received her M.A. in Economics from the Andrew Young School of Policy Studies, Georgia State University, and her B.S. in Mathematics and Economics from the University of Pittsburgh. Her research focuses on the business value of information technology in large institutional settings.

Amrit Tiwana is a professor of MIS at the University of Georgia. $\mathrm{He}$ is a senior editor for Information Systems Research and on the editorial boards of Strategic Management Journal and Journal of Management Information System. His work has appeared in Information Systems Research, Strategic Management Journal, Journal of Management Information Systems, Decision Sciences, ACM Transactions on Software Engineering, and others. 


\title{
Fit ANd Misfit OF PluRAL SOURCING StRategies AND IT-ENABLED PROCESS INTEGRATION CAPABILITIES: CONSEQUENCES OF FIRM PERFORMANCE IN THE U.S. ELECTRIC UTILITY INDUSTRY
}

\author{
Arun Rai \\ Center for Process Innovation and Department of Computer Information Systems, \\ Robinson College of Business, Georgia State University, \\ Atlanta, GA 30303 U.S.A. \{arunrai@gsu.edu\} \\ Ilgaz Arikan \\ College of Business Administration, Kent State University, \\ Kent, OH 44242 U.S.A. \{iarikan@kent.edu\} \\ Jessica Pye \\ Center for Process Innovation and Department of Computer Information Systems, \\ Robinson College of Business, Georgia State University, \\ Atlanta, GA 30303 U.S.A. \{jessica.pye@eci.gsu.edu\}

\section{Amrit Tiwana} \\ Terry College of Business, University of Georgia, \\ Athens, GA 30602 U.S.A. \{tiwana@uga.edu\}
}

\section{Appendix A}

\section{Additional Estimations for the ROA Models and Other Firm Performance Measures}

In addition to the pooled OLS estimations with $\mathrm{ROA}_{\mathrm{t}+1}$ as the measure of firm performance that are reported in the paper, we estimated the models using random effects (RE) and fixed effects (FE) specifications. The RE and FE results, which are reported in Table A1, were consistent with the pooled OLS results and supported $\mathrm{H} 1$ and $\mathrm{H} 2$.

We also evaluated our hypotheses using two additional firm performance measures: Tobin's Q, which is the total dollar amount market value divided by the total dollar amount replacement value of a firm in a given year) and operating revenue/total assets, which is the total dollar amount of revenue divided by total dollar amount of assets of a firm in a given year. We selected these measures because Tobin's Q provides a forward-looking market measure and operating revenue/total assets provides an operating efficiency assessment (Bharadwaj 2000; Bharadwaj et al. 1999). For the Tobin's Q and operating revenue/total assets models, we employed the Breusch and Pagan Lagrangian multiplier test against the null hypothesis that the coefficients estimated by the RE estimator are not systematically different than those of the OLS estimator

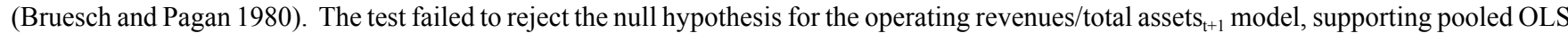
estimation over RE, and rejected the null hypothesis for the Tobin's $Q_{t+1}$ model $\left(\chi^{2}=2.784, p<0.01\right)$, supporting RE estimation over OLS 
estimation. We then examined if FE or RE estimation is to be favored for the Tobin's $\mathrm{Q}_{\mathrm{t}+1}$ model. As we use robust standard errors, we conducted the over-identification test using the Sargan-Hansen statistic against the null hypothesis that the coefficients estimated by the efficient RE estimator are not systematically different from the ones estimated by the consistent FE estimator (Wooldridge 2002). ${ }^{1}$ We rejected this null hypothesis for the Tobin's $\mathrm{Q}_{\mathrm{t}+1}$ model $\left(\chi^{2}=122.14, \mathrm{p}<0.001\right)$, supporting FE estimation over RE estimation. The FE results for the Tobin's $\mathrm{Q}_{\mathrm{t}+1}$ model $^{2}$ and the OLS results for the operating revenue/total assets $\mathrm{t}_{\mathrm{t}+1}$ model are provided in Table A1. Consistent with the results using ROA as the measure of firm performance, we find support for H1 (INTER $\times$ MSI) using Tobin's Q and operating revenue/total assets as measures of firm performance. However, unlike the results using ROA as the measure of firm performance, we do not find support for H2 $($ INTRA $\times$ MSI) using Tobin's Q and operating revenue/total assets as measures of firm performance.

\begin{tabular}{|c|c|c|c|c|c|c|c|c|}
\hline $\begin{array}{c}\text { Dependent } \\
\text { Variables } \rightarrow\end{array}$ & \multicolumn{2}{|c|}{$\mathrm{ROA}_{\mathrm{t+1}}$} & \multicolumn{2}{|c|}{$\mathrm{ROA}_{t+1}$} & \multicolumn{2}{|c|}{ Tobin's $\mathbf{Q}_{t+1}$} & \multicolumn{2}{|c|}{$\begin{array}{c}\text { Operating } \\
\text { Revenue/Assets }_{\mathrm{t}+1}\end{array}$} \\
\hline Estimation $\rightarrow$ & \multicolumn{2}{|c|}{ Random Effects } & \multicolumn{2}{|c|}{ Fixed Effects } & \multicolumn{2}{|c|}{ Fixed Effects } & \multicolumn{2}{|c|}{ Pooled OLS } \\
\hline Models $\rightarrow$ & Main & Interaction & Main & Interaction & Main & Interaction & Main & Interaction \\
\hline \multirow{2}{*}{ ROA } & $0.536^{\star \star \star}$ & $0.540^{* \star *}$ & $0.175^{\star \star}$ & $0.185^{\star \star}$ & & & & \\
\hline & $(0.071)$ & $(0.068)$ & $(0.074)$ & $(0.073)$ & & & & \\
\hline \multirow{2}{*}{ Tobin's Q } & & & & & $0.388^{\star \star \star}$ & $0.385^{\star \star \star}$ & & \\
\hline & & & & & $(0.095)$ & $(0.096)$ & & \\
\hline \multirow{2}{*}{\begin{tabular}{|l|} 
Oper Rev/ \\
Assets $^{\mathrm{b}}$ \\
\end{tabular}} & & & & & & & $0.797^{\star * *}$ & $0.797^{\star \star *}$ \\
\hline & & & & & & & $(0.040)$ & $(0.040)$ \\
\hline \multirow{2}{*}{$\mathrm{MSI}^{\mathrm{a}}$} & $-0.005^{\star}$ & $-0.006^{*}$ & -0.007 & -0.006 & $-0.156^{\star \star}$ & $-0.156^{\star \star}$ & -0.002 & 0.002 \\
\hline & $(0.003)$ & $(0.003)$ & $(0.007)$ & $(0.007)$ & $(0.075)$ & $(0.075)$ & $(0.088)$ & $(0.087)$ \\
\hline \multirow{2}{*}{ INTER $^{b}$} & $0.004^{\star \star \star}$ & $0.002^{\star \star \star}$ & 0.003 & 0.000 & -0.004 & $-0.004^{*}$ & -0.008 & $-0.017^{\star \star}$ \\
\hline & $(0.001)$ & $(0.000)$ & $(0.002)$ & $(0.001)$ & $(0.005)$ & $(0.003)$ & $(0.008)$ & (0.007) \\
\hline \multirow{2}{*}{ INTRA $^{b}$} & -0.001 & $-0.003^{\star \star}$ & $-0.001^{\dagger}$ & $-0.003^{\star \star \star}$ & $-0.011^{*}$ & -0.004 & $-0.020^{\star \star}$ & -0.011 \\
\hline & $(0.001)$ & $(0.001)$ & $(0.001)$ & $(0.001)$ & $(0.006)$ & $(0.010)$ & $(0.009)$ & $(0.023)$ \\
\hline \multirow{2}{*}{$\mathrm{INTER}^{\mathrm{b}} \times \mathrm{MSI}^{\mathrm{a}}$} & & $0.011^{* \star *}$ & & $0.016^{* \star *}$ & & $0.017^{* \star}$ & & $0.039^{\star *}$ \\
\hline & & $(0.003)$ & & $(0.003)$ & & (0.007) & & (0.018) \\
\hline \multirow{2}{*}{$\mathrm{INTRA}^{\mathrm{b}} \times \mathrm{MSI}^{\mathrm{a}}$} & & $-0.017^{* *}$ & & $-0.016^{* * *}$ & & 0.050 & & 0.056 \\
\hline & & $(0.008)$ & & $(0.005)$ & & $(0.053)$ & & $(0.103)$ \\
\hline \multirow{2}{*}{ INTER_MOD ${ }^{b}$} & 0.000 & 0.000 & $-0.001^{\star \star}$ & $-0.001^{\star \star}$ & -0.002 & -0.002 & 0.000 & 0.000 \\
\hline & $(0.000)$ & $(0.000)$ & $(0.000)$ & $(0.000)$ & $(0.008)$ & $(0.008)$ & $(0.007)$ & $(0.007)$ \\
\hline \multirow{2}{*}{ INTRA_MOD } & $-0.002^{* \star *}$ & $-0.002^{* *}$ & $-0.003^{* *}$ & $-0.002^{*}$ & -0.006 & -0.005 & -0.003 & -0.002 \\
\hline & $(0.001)$ & $(0.001)$ & $(0.001)$ & $(0.001)$ & $(0.008)$ & $(0.008)$ & $(0.007)$ & $(0.007)$ \\
\hline \multirow{2}{*}{$\begin{array}{l}\text { IT } \\
\text { Customization }\end{array}$} & $0.002^{* *}$ & 0.001 & 0.001 & 0.001 & $0.013^{*}$ & 0.009 & $0.028^{\star *}$ & $0.027^{\star *}$ \\
\hline & $(0.001)$ & $(0.001)$ & $(0.001)$ & $(0.001)$ & $(0.008)$ & $(0.008)$ & $(0.011)$ & $(0.011)$ \\
\hline
\end{tabular}

\footnotetext{
${ }^{1}$ We used the XTOVERID program (version 2.1.6; 2Nov2011) by Schaffer and Stillman (2006) for the Stata software package. We also conducted the Hausman test with FE and RE specifications without robust standard errors, as the Hausman test is only applicable when the models are not specified with robust standard errors (Hayashi 2000, p. 234, note 18). The Hausman test suggests that the FE estimation should be preferred over RE estimation.

${ }^{2}$ As a FE specification of "Small T and Large N" (few time periods and many firms) that includes lagged dependent variable on the right-hand-side of the equation can produce biased estimates (Roodman 2009), we employed dynamic panel estimation to further examine the Tobin's $\mathrm{Q}_{t+1}$ model. We used the XTABOND2 Stata procedure for the Arellano-Bover/Blundell-Bond System Generalized Method of Moments (GMM) estimator (Arellano and Bond 1991; Arellano and Bover 1995; Blundell and Bond 1998). As with the FE results, we observed the System GMM results to support H1 and not H2.
} 


\begin{tabular}{|c|c|c|c|c|c|c|c|c|}
\hline $\begin{array}{c}\text { Dependent } \\
\text { Variables } \rightarrow\end{array}$ & \multicolumn{2}{|c|}{$\mathbf{R O A}_{\mathrm{t+1}}$} & \multicolumn{2}{|c|}{$\mathrm{ROA}_{\mathrm{t}+1}$} & \multicolumn{2}{|c|}{ Tobin's $\mathbf{Q}_{t+1}$} & \multicolumn{2}{|c|}{$\begin{array}{c}\text { Operating } \\
\text { Revenue/Assets }_{\mathrm{t}+1}\end{array}$} \\
\hline Estimation $\rightarrow$ & \multicolumn{2}{|c|}{ Random Effects } & \multicolumn{2}{|c|}{ Fixed Effects } & \multicolumn{2}{|c|}{ Fixed Effects } & \multicolumn{2}{|c|}{ Pooled OLS } \\
\hline Models $\rightarrow$ & Main & Interaction & Main & Interaction & Main & Interaction & Main & Interaction \\
\hline \multirow{2}{*}{$\begin{array}{l}\text { IT } \\
\text { Infrastructure }\end{array}$} & -0.001 & -0.001 & $-0.001^{\dagger}$ & -0.001 & -0.005 & -0.004 & $-0.012^{\star \star}$ & $-0.012^{*}$ \\
\hline & $(0.001)$ & $(0.001)$ & $(0.001)$ & $(0.001)$ & $(0.006)$ & $(0.006)$ & $(0.006)$ & $(0.006)$ \\
\hline \multirow{2}{*}{\begin{tabular}{|l|} 
Supplier \\
Concentration
\end{tabular}} & -0.004 & -0.005 & -0.002 & -0.001 & -0.017 & -0.018 & 0.053 & 0.054 \\
\hline & $(0.003)$ & $(0.003)$ & $(0.004)$ & $(0.004)$ & $(0.034)$ & $(0.034)$ & $(0.083)$ & $(0.084)$ \\
\hline \multirow{2}{*}{ Oil Crisis Shock } & 0.003 & 0.002 & $0.005^{\star \star}$ & $0.005^{\star *}$ & $-0.028^{*}$ & -0.025 & 0.058 & 0.059 \\
\hline & $(0.002)$ & $(0.002)$ & $(0.003)$ & $(0.002)$ & $(0.017)$ & $(0.017)$ & $(0.036)$ & $(0.036)$ \\
\hline \multirow{2}{*}{\begin{tabular}{|l|} 
Depreciation \\
Expenses $^{\mathrm{b}}$
\end{tabular}} & 0.000 & 0.000 & $-0.001^{\dagger}$ & $-0.001^{\dagger}$ & -0.001 & -0.003 & 0.011 & 0.010 \\
\hline & $(0.001)$ & $(0.001)$ & $(0.001)$ & $(0.001)$ & $(0.007)$ & $(0.007)$ & $(0.012)$ & $(0.012)$ \\
\hline \multirow{2}{*}{ Firm Age $^{b, c}$} & 0.001 & 0.001 & -0.006 & -0.006 & -0.007 & -0.006 & 0.038 & 0.038 \\
\hline & $(0.001)$ & $(0.001)$ & $(0.004)$ & $(0.004)$ & $(0.049)$ & $(0.050)$ & $(0.027)$ & $(0.027)$ \\
\hline \multirow{2}{*}{$\begin{array}{l}\text { Production } \\
\text { Capacity, d }\end{array}$} & 0.000 & 0.000 & -0.002 & -0.001 & 0.011 & 0.009 & -0.001 & -0.002 \\
\hline & $(0.001)$ & $(0.001)$ & $(0.002)$ & $(0.002)$ & $(0.015)$ & $(0.014)$ & $(0.031)$ & $(0.031)$ \\
\hline \multirow{2}{*}{ CWIP_Other ${ }^{b}$} & -0.001 & -0.001 & $-0.002^{*}$ & $-0.002^{*}$ & -0.015 & -0.014 & -0.012 & -0.011 \\
\hline & $(0.001)$ & $(0.001)$ & $(0.001)$ & $(0.001)$ & $(0.009)$ & $(0.009)$ & $(0.013)$ & $(0.014)$ \\
\hline \multirow{2}{*}{ Constant } & $0.025^{\star \star \star}$ & $0.025^{\star \star \star}$ & $0.045^{\star \star \star}$ & $0.044^{* \star \star}$ & $0.603^{\star \star \star}$ & $0.607^{\star \star \star}$ & $0.070^{* \star \star}$ & $0.070^{\star \star *}$ \\
\hline & $(0.004)$ & $(0.004)$ & $(0.004)$ & $(0.004)$ & $(0.083)$ & $(0.084)$ & $(0.025)$ & $(0.024)$ \\
\hline F-statistic & $13.010^{* *}$ & $14.920^{\star \star \star}$ & $3.601^{* \star *}$ & $10.824^{\star \star \star}$ & 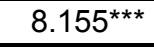 & $74.724^{\star * \star}$ & $46.242^{* * *}$ & $66.724^{\star * *}$ \\
\hline Firms & 121 & 121 & 133 & 133 & 109 & 109 & 113 & 113 \\
\hline $\begin{array}{l}\text { Firm-Year } \\
\text { Observations }\end{array}$ & 805 & 805 & 886 & 886 & 687 & 687 & 762 & 762 \\
\hline
\end{tabular}

Notes: Unstandardized coefficients reported. Standard errors are in parentheses. Robust standard errors used, clustered at the firm level for OLS and RE estimations.

Dummies included for NERC region of a firm in models that were not FE estimations.

${ }^{*} p<0.10,{ }^{* *} p<0.05,{ }^{* * *}<0.01$.

${ }^{\dagger}$ Effects are significant at $p<0.10$; coefficients and standard errors shown have been rounded.

${ }^{a}$ These variables are mean centered.

${ }^{\mathrm{b}}$ These variables are standardized to z-scores.

${ }^{\circ} 0$ replaced by 0.1 to be able to take the log.

${ }^{d}$ Winsorized at $5 \%$ tails; results stable without winsorizing. 


\section{Appendix B}

\section{Endogeneity Assessment of MSI Using Two-Step Generalized Method of Moments}

We used the XTIVREG2 two-step generalized method of moments (GMM) procedure in Stata (Schaffer 2005) to evaluate if MSI was endogenous in the ROA model. The results are summarized in Table B1. We briefly describe the two-stage process that we employed.

Stage 1: We estimated MSI using the following three instrumental variables (Deregulation Shock, Log Total Plants $\mathrm{t}_{\mathrm{t}-1}$, INTER_MOD $\mathrm{IN}_{\mathrm{t}-1}$ ). We also included the following variables in estimating MSI: INTER, INTRA, IT customization, IT Infrastructure, Supplier Concentration, Oil Crisis Shock, Depreciation Expenses, Firm Age, Production Capacity, and CWIP_Other.

Stage 2: We included the MSI estimates in Stage 2, with ROA as the dependent variable. However, we did not include the interactions (MSI $\times$ INTRA/INTER) for the following reasons: There are two ways to go about including interaction terms with the endogenous variable in our specification. First, if $\mathrm{Y}$ is the endogenous variable, $\mathrm{X} 1$ is the exogenous variable, and $\mathrm{Y} \times \mathrm{X} 1$ is to be included in the second stage, then in the first stage the excluded instrument $(Z)$ needs to be interacted as $Z \times X 1$. We have three excluded instruments, requiring the addition of six interaction terms in Stage 1 (the three excluded instruments interacted with INTER and INTRA, respectively). When we included these six interaction terms in Stage 1, the models suffered from excessive multicollinearity and did not converge. Second, one can include instrumental variables in Stage 1 that correlate only with the interaction term but not with the variables that comprise the interaction terms. We are not aware of any instrumental variables to make this inclusion feasible. Furthermore, the results suggest that MSI is not endogenously determined, which makes us more confident about our approach. 


\begin{tabular}{|c|c|c|}
\hline Variables & First Stage & Second Stage \\
\hline \multirow{2}{*}{ ROA } & $0.754^{*}$ & 0.099 \\
\hline & $(0.440)$ & $(0.076)$ \\
\hline \multirow{2}{*}{$\mathrm{MSI}^{\mathrm{a}}$} & & 0.004 \\
\hline & & $(0.022)$ \\
\hline \multirow{2}{*}{ INTER ${ }^{b}$} & 0.005 & $0.003^{* *}$ \\
\hline & $(0.004)$ & $(0.002)$ \\
\hline \multirow{2}{*}{ INTRA $^{b}$} & 0.003 & $-0.002^{\star *}$ \\
\hline & $(0.006)$ & $(0.001)$ \\
\hline \multirow{2}{*}{ INTER_MOD } & -0.002 & $-0.001^{\dagger}$ \\
\hline & $(0.003)$ & $(0.001)$ \\
\hline \multirow{2}{*}{ INTRA_MOD ${ }^{b}$} & -0.002 & -0.002 \\
\hline & $(0.006)$ & $(0.002)$ \\
\hline \multirow{2}{*}{ IT Customization ${ }^{b}$} & -0.009 & 0.001 \\
\hline & $(0.007)$ & $(0.001)$ \\
\hline \multirow{2}{*}{ IT Infrastructure ${ }^{b}$} & -0.005 & -0.001 \\
\hline & $(0.004)$ & $(0.001)$ \\
\hline \multirow{2}{*}{ Supplier Concentration } & 0.039 & -0.002 \\
\hline & $(0.059)$ & $(0.005)$ \\
\hline \multirow{2}{*}{ Oil Crisis Shock } & -0.009 & 0.005 \\
\hline & $(0.106)$ & $(0.005)$ \\
\hline \multirow{2}{*}{ Depreciation Expenses ${ }^{b}$} & -0.003 & -0.001 \\
\hline & $(0.009)$ & $(0.001)$ \\
\hline \multirow{2}{*}{ Firm Age A, c $^{b}$} & 0.007 & -0.007 \\
\hline & $(0.008)$ & $(0.007)$ \\
\hline \multirow{2}{*}{ Production Capacity ${ }^{\mathrm{b}, \mathrm{d}}$} & $-0.082^{* * *}$ & -0.001 \\
\hline & $(0.030)$ & $(0.004)$ \\
\hline \multirow{2}{*}{ CWIP_Other ${ }^{b}$} & 0.003 & $-0.005^{\star *}$ \\
\hline & $(0.006)$ & $(0.002)$ \\
\hline \multirow{2}{*}{ INTER_MOD ${ }_{\mathrm{t}-1}^{\mathrm{b}}$} & $0.020^{* * *}$ & \\
\hline & $(0.003)$ & \\
\hline \multirow{2}{*}{ Deregulation Shock } & 0.004 & \\
\hline & $(0.005)$ & \\
\hline \multirow{2}{*}{ Log Total Plants $\mathrm{t}_{\mathrm{t}-1}$} & $-0.064^{* *}$ & \\
\hline & $(0.031)$ & \\
\hline F-statistic & $5.839^{* * *}$ & $6.921^{\star * *}$ \\
\hline Log-likelihood & 750.878 & 2127.639 \\
\hline Firms & 130 & 130 \\
\hline Firm-Year Observations & 758 & 758 \\
\hline Partial $R^{2}$ of excluded instruments & \multicolumn{2}{|c|}{0.121} \\
\hline Test of excluded instruments (F-statistic) & \multicolumn{2}{|c|}{$12.39^{* * *}$} \\
\hline
\end{tabular}


Table B1. Endogeneity Assessment of MSI for ROA $\mathrm{t}_{t+1}$ (Two-Step GMM) (Continued)

Underidentification tests

Ho: matrix of reduced form coefficients has rank $=\mathrm{K} 1-1$

(underidentified)

Ha: matrix has rank $=\mathrm{K} 1$ (identified)

Kleibergen-Paap rk LM statistic $\left(\chi^{2}\right)$

$21.28^{* * *}$

Kleibergen-Paap rk Wald statistic $\left(\chi^{2}\right)$

$38.22^{* * *}$

Weak identification test

Ho: equation is weakly identified

Kleibergen-Paap Wald rk F statistic

$12.39^{* * \star}$

Weak-instrument-robust inference

Tests of joint significance of endogenous regressors B1 in main equation

Ho: $B 1=0$ and overidentifying restrictions are valid

Anderson-Rubin Wald test F-statistic

Anderson-Rubin Wald test $\chi^{2}$

Stock-Wright LM S statistic $\chi^{2}$

0.06 ( $\mathrm{p}$-value $>0.90)$

$0.17(p$-value $>0.90)$

0.15 ( $p$-value $>0.90)$

Hansen J statistic $\left(\chi^{2}\right)$ (overidentification test of all instruments)

$0.12(p-$ value $>0.90)$

Endogeneity test of endogenous regressor (MSI)

Number of regressors

Number of instruments

Number of excluded instruments

Instrumented

0.15 ( $p$-value $>0.70)$

\begin{tabular}{l|l}
\hline Excluded instruments & Dereg. Shock,
\end{tabular}

14

16

3

$\mathrm{MSI}$

INTER_MOD ${ }_{t-1}^{b}$,

InTotalPlants ${ }_{t-1}$

Notes: Unstandardized coefficients reported.

${ }^{*} p<0.10,{ }^{* *} p<0.05,{ }^{* * *} p<0.01,{ }^{* * * *} p<0.001$

${ }^{\dagger}$ Effects are significant at $p<0.10$; coefficients and standard errors shown are rounded.

Standard errors are in parentheses.

${ }^{a}$ These variables are mean centered.

${ }^{\mathrm{b}}$ These variables are standardized to z-scores.

${ }^{\circ} 0$ replaced by 0.1 to be able to take the log.

${ }^{d}$ Winsorized at $5 \%$ tails; results stable without winsorizing. 


\section{References}

Arellano, M., and Bond, S. 1991. "Some Tests of Specification for Panel Data: Monte Carlo Evidence and an Application to Employment Equations," Review of Economic Studies (58:2), pp. 277-297.

Arellano, M., and Bover, O. 1995. "Another Look at the Instrumental Variable Estimation of Error-Components Models," Journal of Econometrics (68:1), pp. 29-51.

Bharadwaj, A. S. 2000. "A Resource-Based Perspective on Information Technology Capability and Firm Performance: An Empirical Investigation," MIS Quarterly (24:1), pp. 169-196.

Bharadwaj, A. S., Bharadwaj, S. G., and Konsynski, B. R. 1999. "Information Technology Effects on Firm Performance as Measured by Tobin's Q," Management Science (45:7), pp. 1008-1024.

Blundell, R., and Bond, S. 1998. "Initial Conditions and Moment Restrictions in Dynamic Panel-Data Models," Journal of Econometrics (87:1), pp. 115-143.

Breusch, T., and Pagan, A. 1980. "The Lagrange Multiplier Test and its Applications to Model Specifications in Econometrics," The Review of Economic Studies (47:1), pp. 239-253.

Hayashi, F. 2000. Econometrics, Princeton, NJ: Princeton University Press.

Roodman, D. 2009. "How to Do xtabond2: An Introduction to Difference and System GMM in Stata," Stata Journal (9:1), pp. 86-136.

Schaffer, M. 2005. "XTIVREG2: Stata Module to Perform Extended IV/2SLS, GMM and AC/HAC, LIML and K-Class Regression for Panel Data Models," Statistical Software Components S4254010, Department of Economics, Boston College.

Schaffer, M., and Stillman, S. 2006. "XTOVERID: Stata Module to Calculate Tests of Overidentifying Restrictions After xtreg, xtivreg, xtivreg2, xthtaylor," Statistical Software Components S456779, Department of Economics, Boston College.

Wooldridge, J. 2002. Econometric Analysis of Cross Section and Panel Data, Cambridge, MA: MIT Press. 
Copyright of MIS Quarterly is the property of MIS Quarterly and its content may not be copied or emailed to multiple sites or posted to a listserv without the copyright holder's express written permission. However, users may print, download, or email articles for individual use. 